$$
3
$$




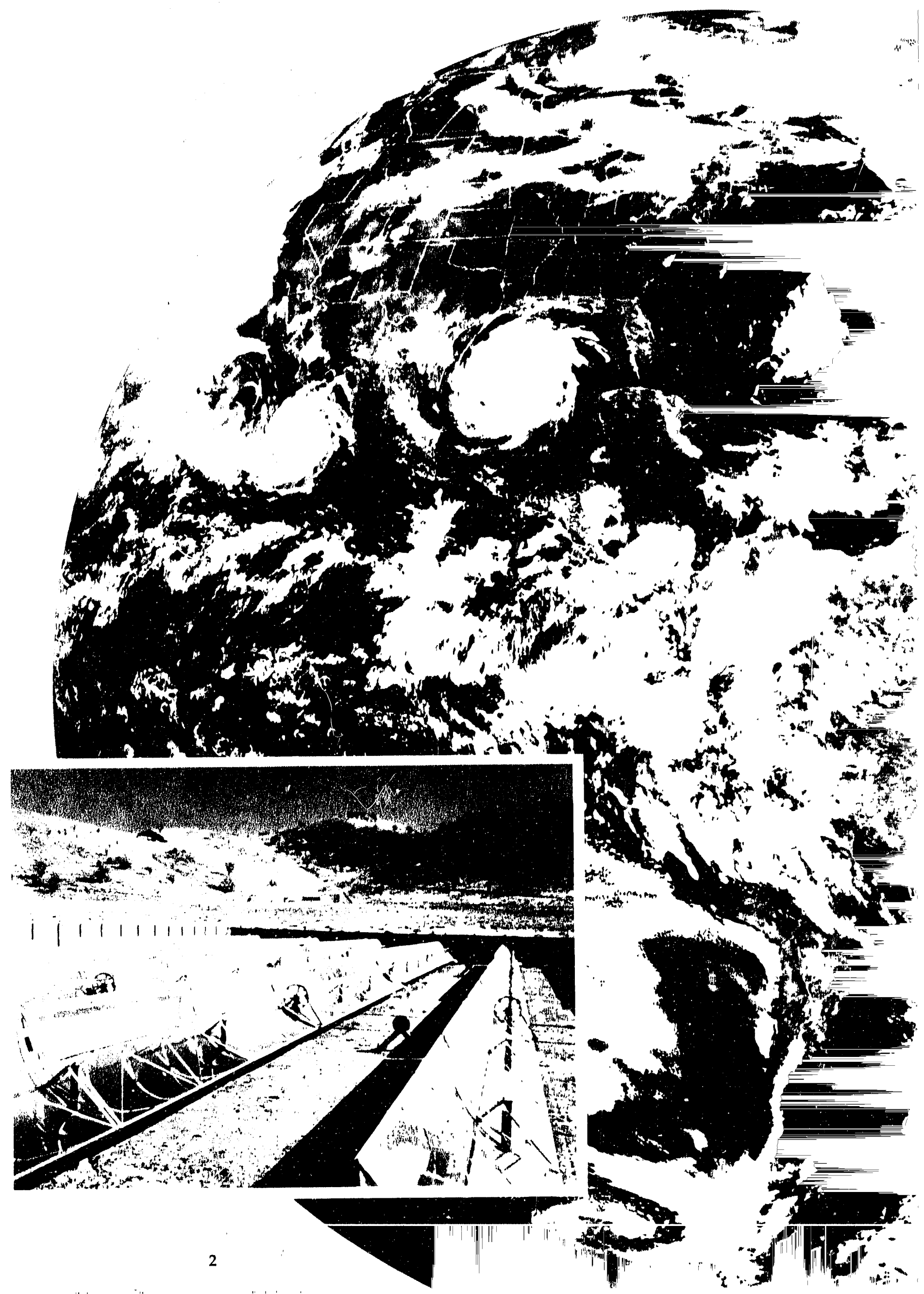




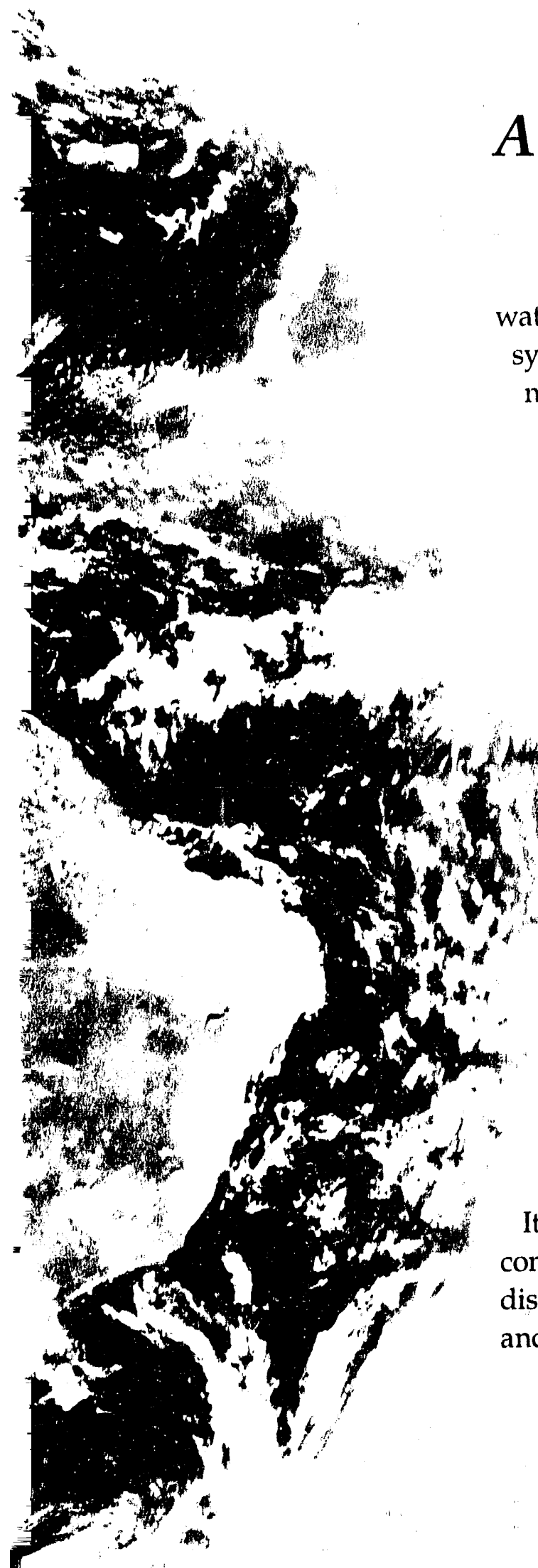

\section{A Primer on Solar Radiation Data}

correctional institution in Tehachapi, California uses solar energy to supplement the existing boiler system to provide hot water and space heating for 5100 people. This privately owned system provides energy at a cost below the commercial rate for natural gas heating. Sunlight striking the two acres of troughs is reflected and concentrated onto tubes carrying a glycol/ water antifreeze solution that runs the length of the troughs. The solution, heated to $270^{\circ} \mathrm{F}$, is piped away and circulated through a heat exchanger to provide hot water for showers, kitchens, laundries, and space heating.

Engineers based their design of the system, built in 1990 , on the available sunshine, the efficiency of the existing boiler system, the effectiveness of the collector troughs in tracking the sun and concentrating its rays on the tubes carrying collector fluid, the efficiency of the heat exchanger, and the system reliability. All this information was vital not only to the design of the system but also to its evaluation, its operation, and even to the decision to go ahead and build the system.

Accurate information is important for designing energy systems. This primer examines one of the most important pieces of information - solar radiation data. It explains what solar radiation data are, why they are needed, what data are measured, how the data are used, and how data uncertainties affect performance and economic projections.

It also examines how climate, geography, and atmospheric conditions cause the amount of solar radiation to vary, and it discusses solar radiation data bases and products available (now and in the near future) for engineering and economic analyses. 


\section{hat are solar radiation data?}

Solar radiation data provide information on how much of the sun's energy strikes a surface at a location on earth during a particular time period. The data give values of energy per unit of area. By showing naturally occurring changes in the amount of solar radiation over the course of days, months, and years, these data determine the amount of solar radiation for a location. The units of measurement are expressed as kilowatt-hours per square meter $\left(\mathrm{kWh} / \mathrm{m}^{2}\right)$, megajoules per square meter $\left(\mathrm{M} J / \mathrm{m}^{2}\right)$, langleys $(\mathrm{L})$, or British thermal units per square foot $\left(\mathrm{Btu} / \mathrm{ft}^{2}\right)$.

Today, the primary source of solar radiation data for the United States comes from measurements made by the National Weather Service at 26 SOLMET (SOLar METeorological) stations from 1952 to 1975. In addition, mathematical models estimated data for 222 ERSATZ (synthetic) stations where no solar radiation measurements were made. Because the equipment did not always accurately measure the solar radiation and the models used were limited in their application, the data do not always correlate well with more recent field measurements. To provide better data, we developed a National Solar Radiation Data Base. This data base covers 30 years (1961-1990) and comes from information recorded by more accurate instruments and from better models. In 1992, this new data base will be available for 25() sites.
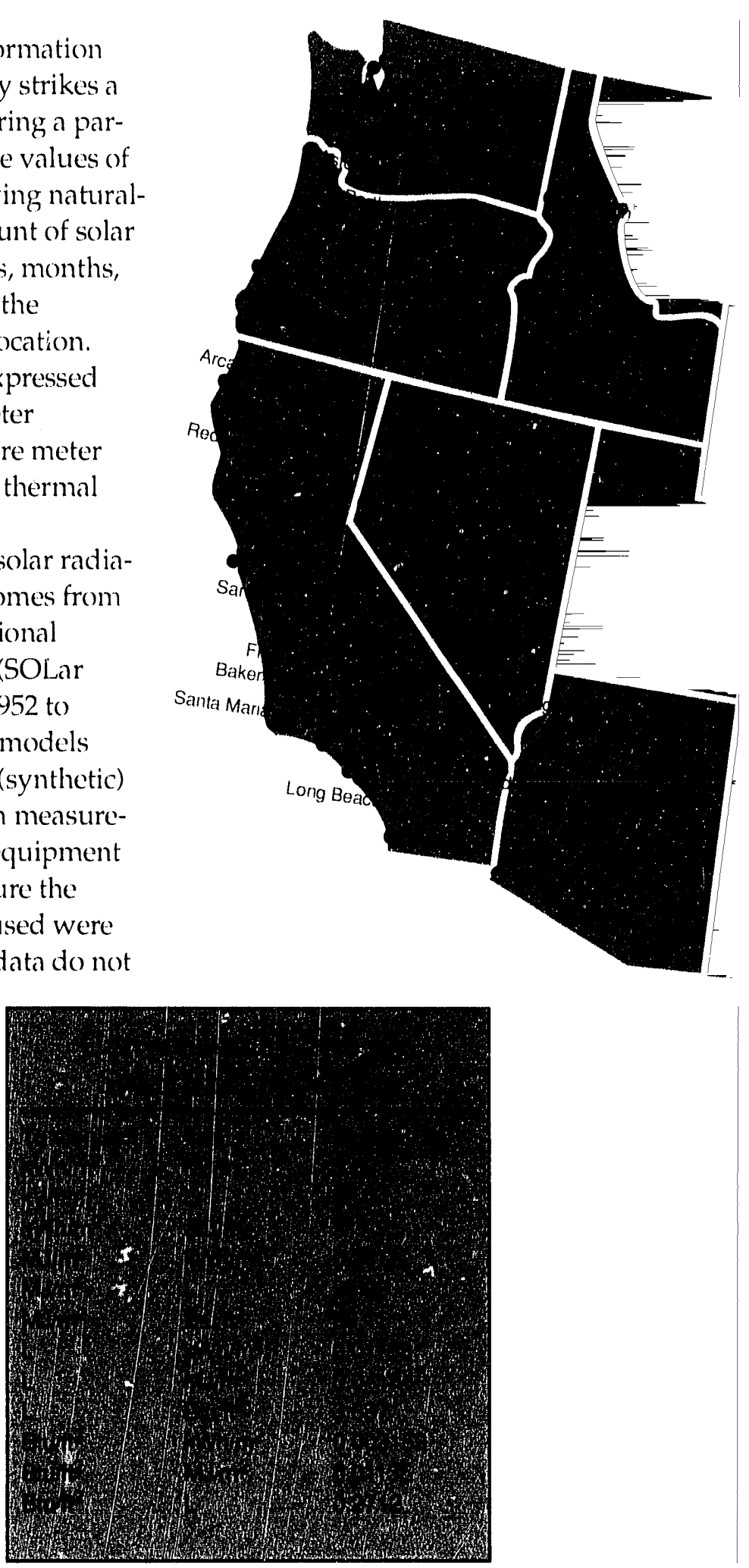


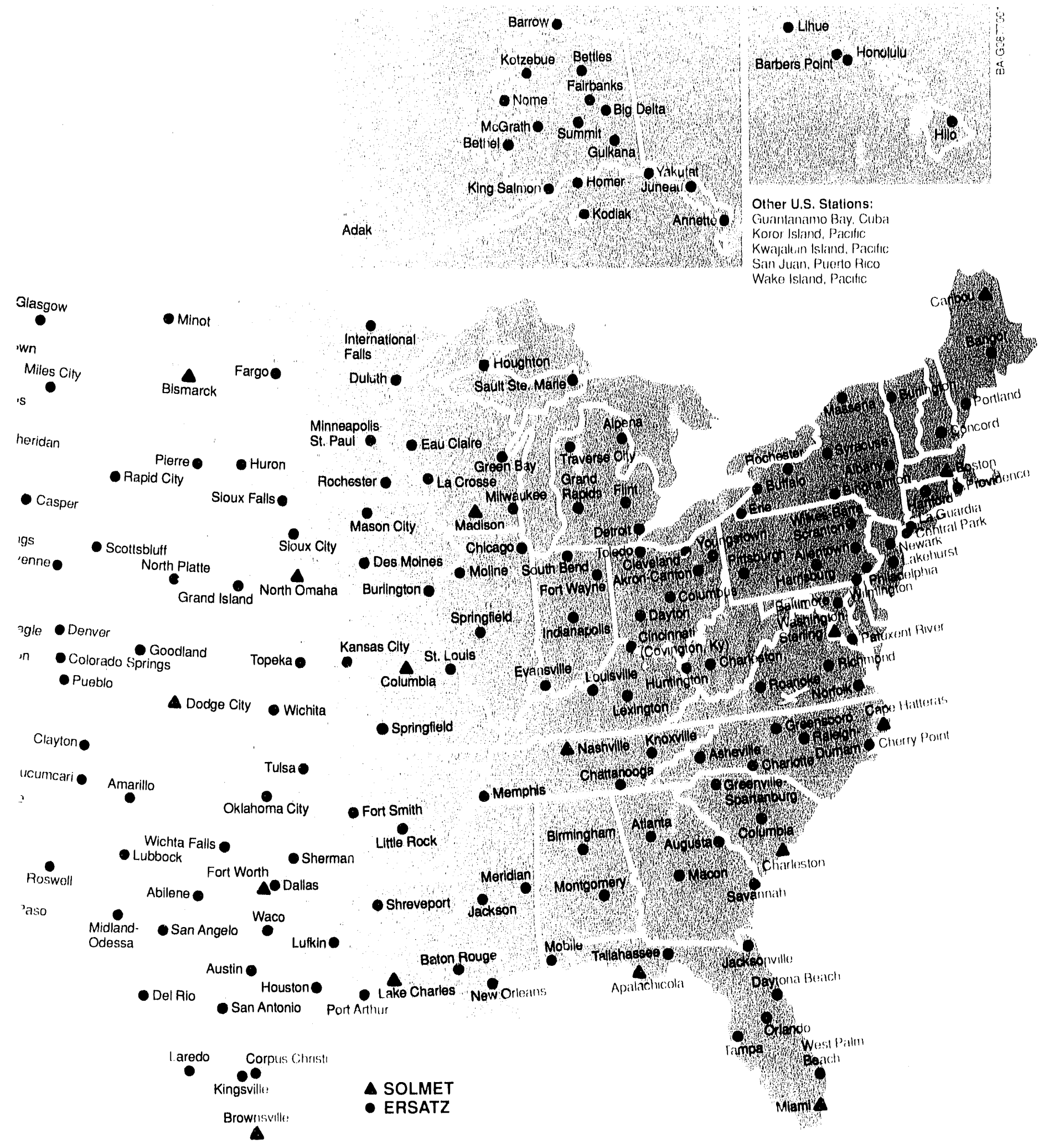

Irom 1952 to 1975 solar radiation was measured .1 26 SOI.ML:T stations ( $\Delta$ ) and modeled for 222 I:RSATK stations ( $\bullet$ ). Most of these stations will he included in the new National Solar Radiation Dala Base. 


\section{hy do we need solar radiation data?}

The earth receives a vast amount of energy from the sun in the form of solar radiation. If we converted to usable energy just $0.2 \%$ of the solar radiation that falls on our nation, we would meet the energy demand of the entire United States. A variety of solar energy technologies are being developed to harness the sun's energy including:

- solar electric (photovoltaic) for converting sunlight directly into electricity;

- solar heat (thermal) for heating water for industrial and household uses;

- solar thermal electric for producing steam to run turbines that generate electricity;

- solar fuel technologies for converting biomass (plants, crops, and trees) into fuels and by-products;

- passive solar for lighting and heating buildings; and

- solar detoxification for destroying hazardous waste with concentrated sunlight.

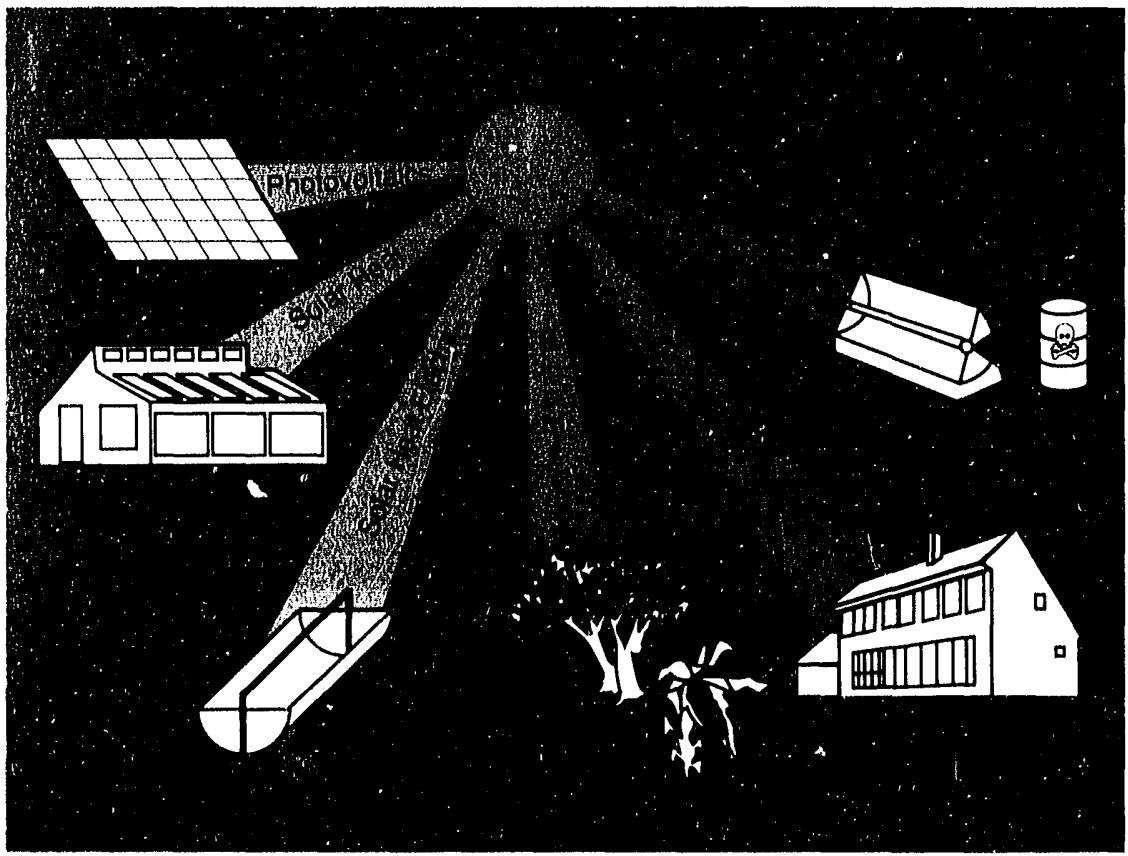

These technologies convert sunlight into usable forms of energy.

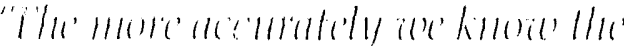

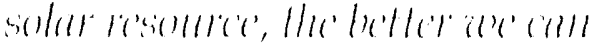

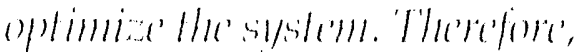

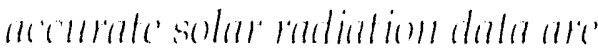
(II) important factor in soldar system itesight.",

David F. Menicucci Sandia National Laboratories

The economics of these technologies depend on the equipment and operating costs, the percentage of the solar radiation that can be converted into the desired energy product, and the amount of solar radiation available. Users of these technologies need high-quality solar radiation data. If the actual solar radiation for a location is less than indicated by available data, the performance and the economic goals for the system will not be met. On the other hand, if the actual solar energy at a location is greater than indicated by the data, the performance and economic projections may be too conservative and prevent a viable technology from being used.

To minimize energy consumption, heating and air conditioning engineers also use solar radiation data to select building configurations, orientations, and air conditioning systems. Because energy costs are a significant expense in building ownership, an energy-efficient design can significantly reduce the life-cycle cost of a building.

The amount of solar radiation received changes throughout the day and year due to weather patterns and the changing position of the sun, and solar radiation data reflects this variability. By knowing the variability, we can size storage systems so they can provide energy at night and during cloudy periods. For technologies 


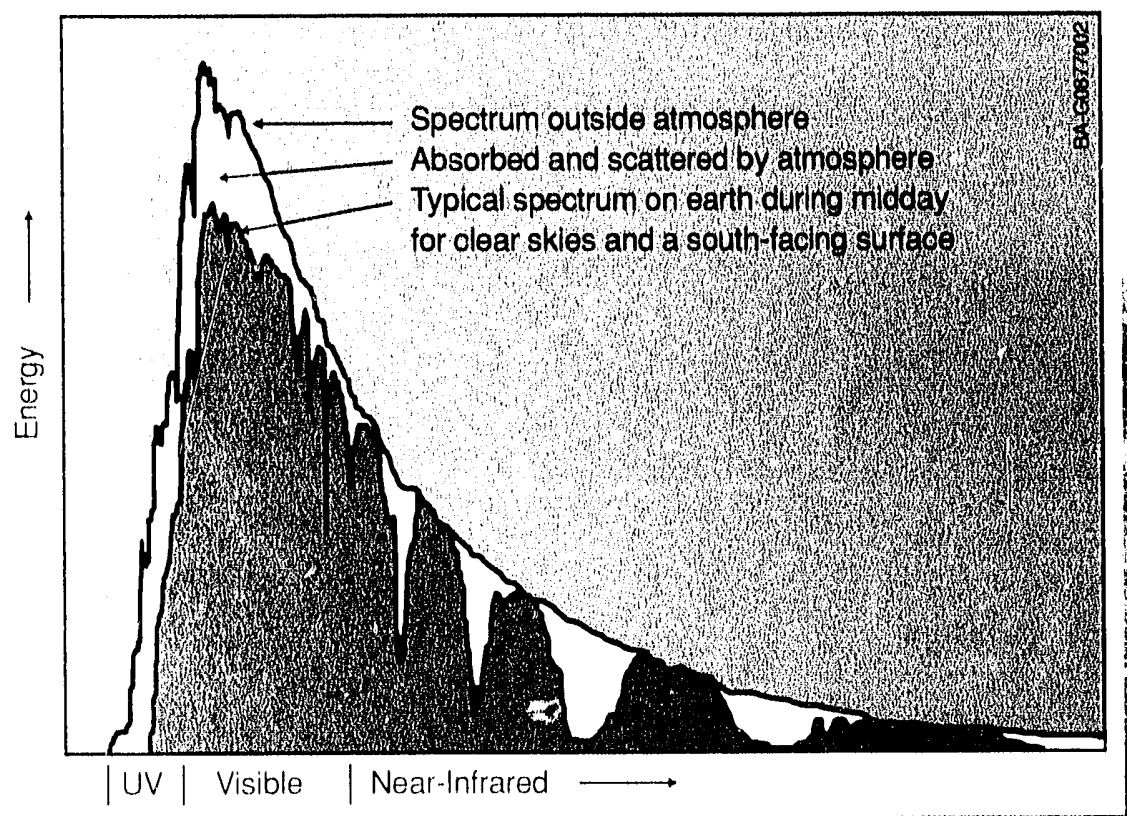

Becouse of absorption and scattering by the atmosphere, the spectral distribution of solar radiation outside the atmosphere differs significantly from that on earth. Also, the spectral distribution on earth changes throughout the day and year and is influenced by location, climate, and atmospheric conditions. Consequently, the percentage of energy that is composed of $U V$, visible, or near-infrared radiation, or portions thereof, also varies by location, time of day, nd year.

with ne cenergy storage, we can evaluate lond matehing by comparing the profile of the available solar radiation throughout the dis with the profile of the energy required by the load. Solar radiation data also help determine the best geographic locations for solar energy technologies. Other factors boing equal, a site receiving more solar radiation will be more coonomical.

fior certain technologies, we also need to know the spectral, or wavelength, distribution of the solar radiation. For example,

photevoltaic devices respond primarily to wavelengthe in the visible and near-infrared region of the spectrum, while solar detexification uses energy from the ultraviolet (UV) region. Location, climate, and atmospheric conditions influence the spectral distribution of solar radiation.

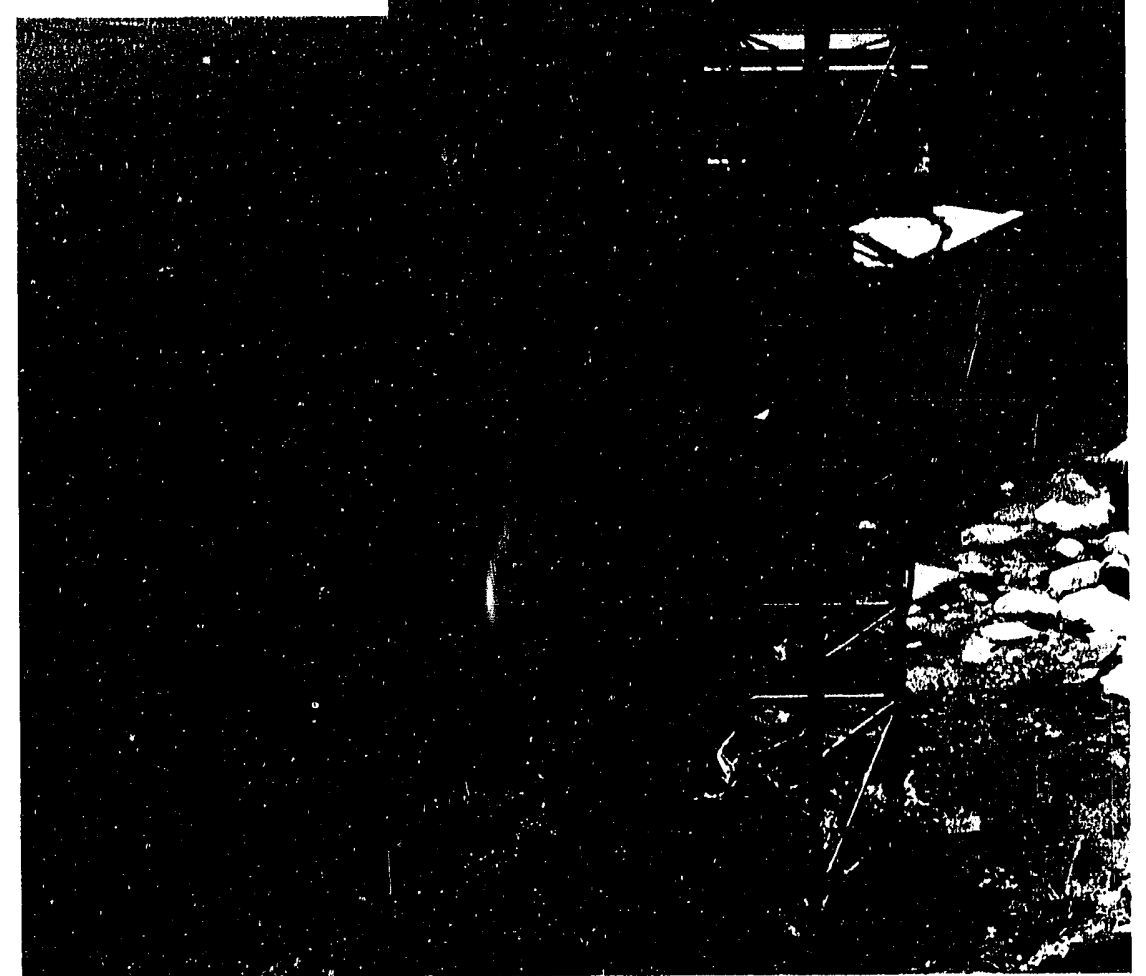

This remote water-level-monitoring station uses photovoltaics for charging storage batteries that supply electric power. Solar radiation data provide information for determining the size of the photovoltaic and battery system needed to supply remote stations like this with reliable electric service. 


\section{hat influences the amount of solar radiation?}

The amount of solar radiation reaching the earth's surface varies greatly because of changing atmospheric conditions and the changing position of the sun, both during the day and throughout the year. Clouds are the predominant atmospheric condition that determines the amount of solar radiation that reaches the earth. Consequently, regions of the nation with cloudy climates receive less solar radiation than the cloudfree desert climates of the southwestern United States. For any given location, the solar radiation reaching the earth's surface decreases with increasing cloud cover.

Local geographical features, such as mountains, oceans, and large lakes, influence the formation of clouds; therefore, the amount of solar radiation received for these areas may be different from that received by adjacent land areas. For example, mountains may receive less solar radiation than adjacent foothills and plains located a short distance away. Winds blowing against mountains force some of the air to rise, and clouds form from the moisture in the air as it cools. Coastlines may also receive a different amount of solar radiation than areas further inland. Where the changes in geography are less pronounced, such as in the Great Plains, the amount of solar radiation varies less.

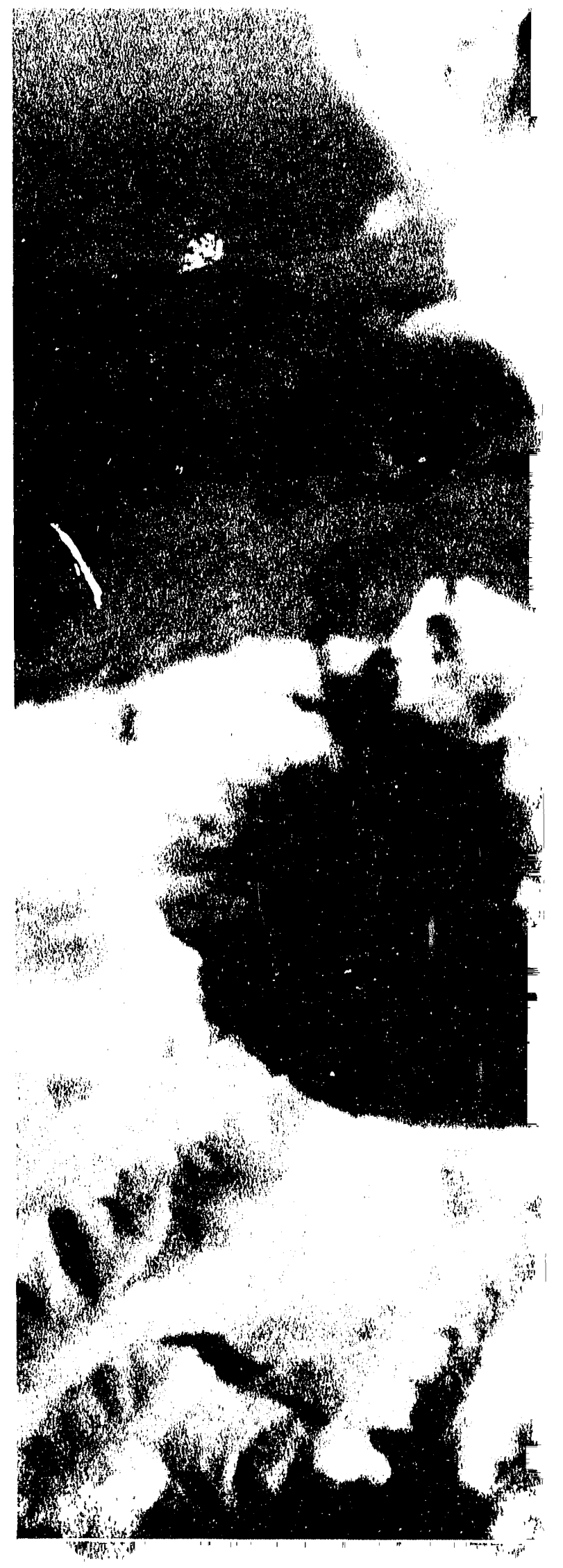




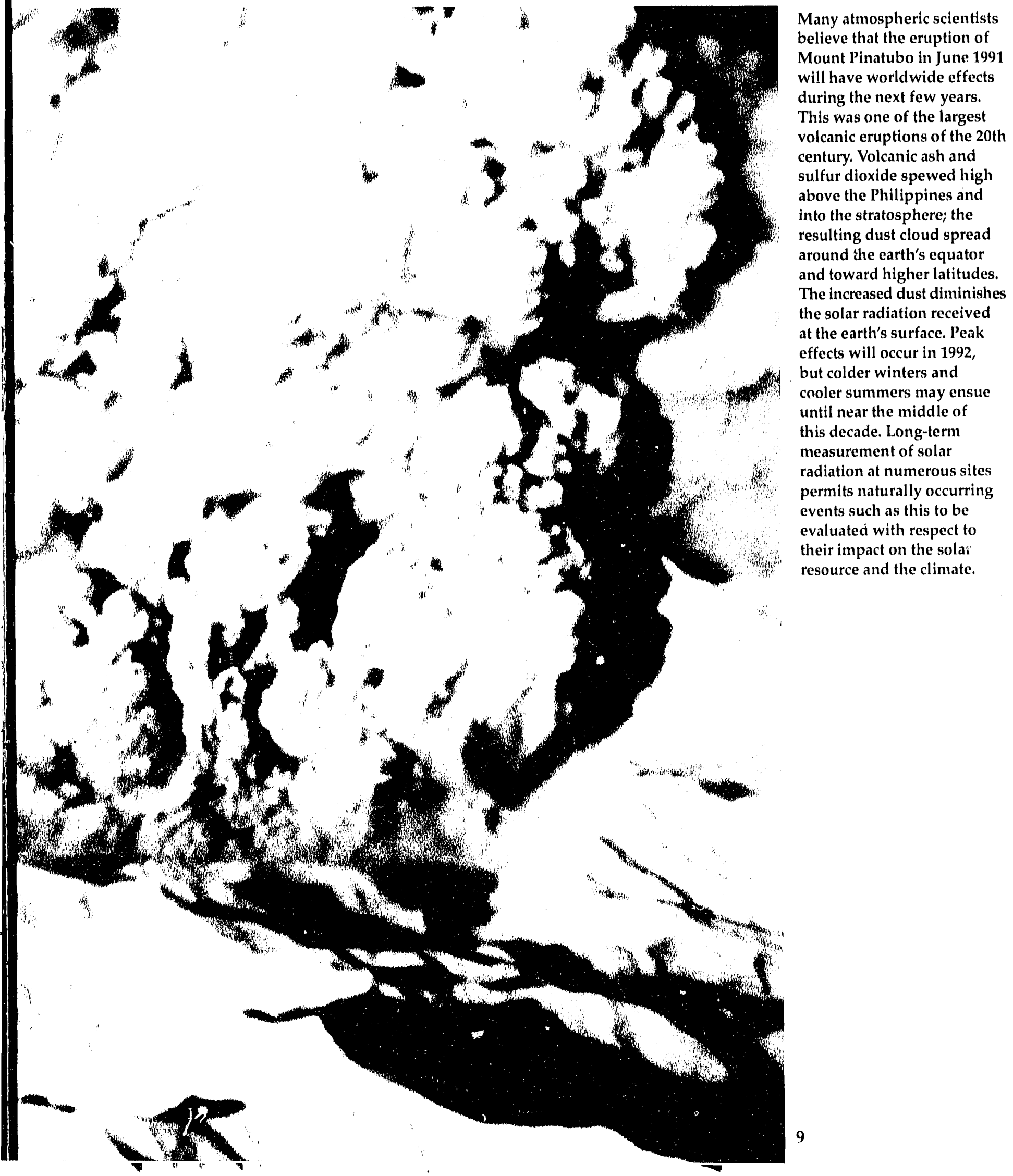




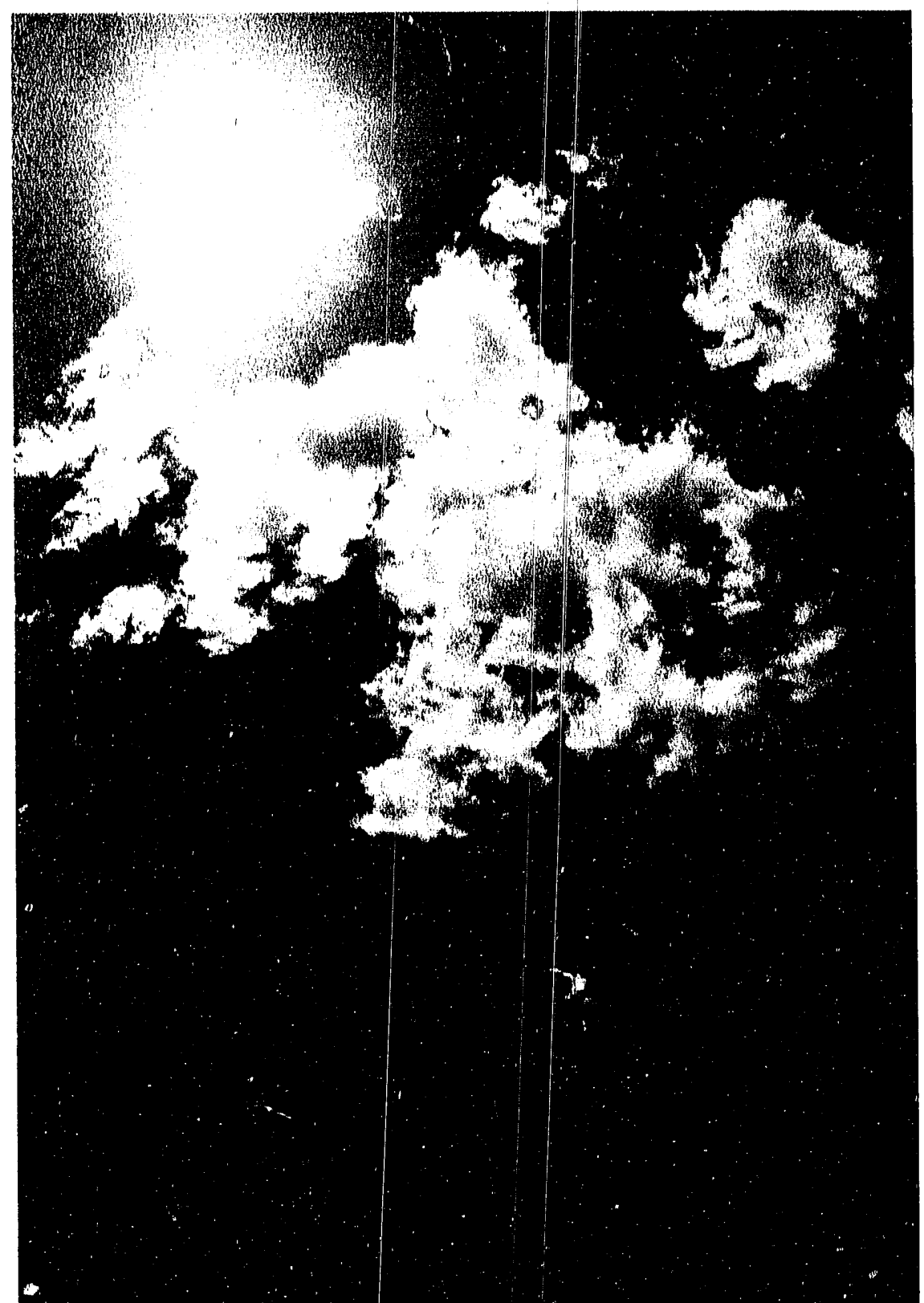

Clouds are the predominant atmospheric condition that determines the amount of solar radiation reaching the earth.
The amount of solar radiation also varies depending on the time of day and the seasom. In general, more solar radiation is present during midtay than during either the carly morning or late afterneon. At midday, the sun is positioned high in the sky and the path of the sun's rays through the earth's atmosphere is shortened. Consequently, less soliar radiation is scattered or absorbed, and more solar radiation reaches the earth's surface. In the northern hemisphere, south-facing collectors also receive more solar radiation during midday becaluse the sun's rays are nearly perpendicular to the collector surface. Thacking collectors can increase the amount of solar radiation recoived by tracking the sum and keeping its rays perpendicular to the collewtor throughout the day. In the northern hemisphere, we also expect more solar radiation during the summer than during the winter because there are more daylight hours. This is more promounced at highere latitudes.

Both man-mate and naturally oceurring avents can limit the amount of solar radiation at the earth's surface. Urban air pollution, smoke from forest fires, and airberne ash resulting from voluanic activity reduce the solar resource by increasing the seattering and absorption of solar radiation. This has a larger impact on radiation coming in a direct line from the sun (direct beam) than on the total (global) solar radiation. Some of the direct beam radiation is scattered loward carth and is called diffuse (sky) radiation (global $=$ direct + diffuse). ('onsicquently, concentrators that use only direct beam soldar radiation are more adversoly affected than collectors that use ginbal solar radiation. ()n a day with severely polluted air (smogs alert), the direct beam solar radiation can be redeced by $40 \%$ whereas the global solar radiation is reduced by $15 \%$ to 


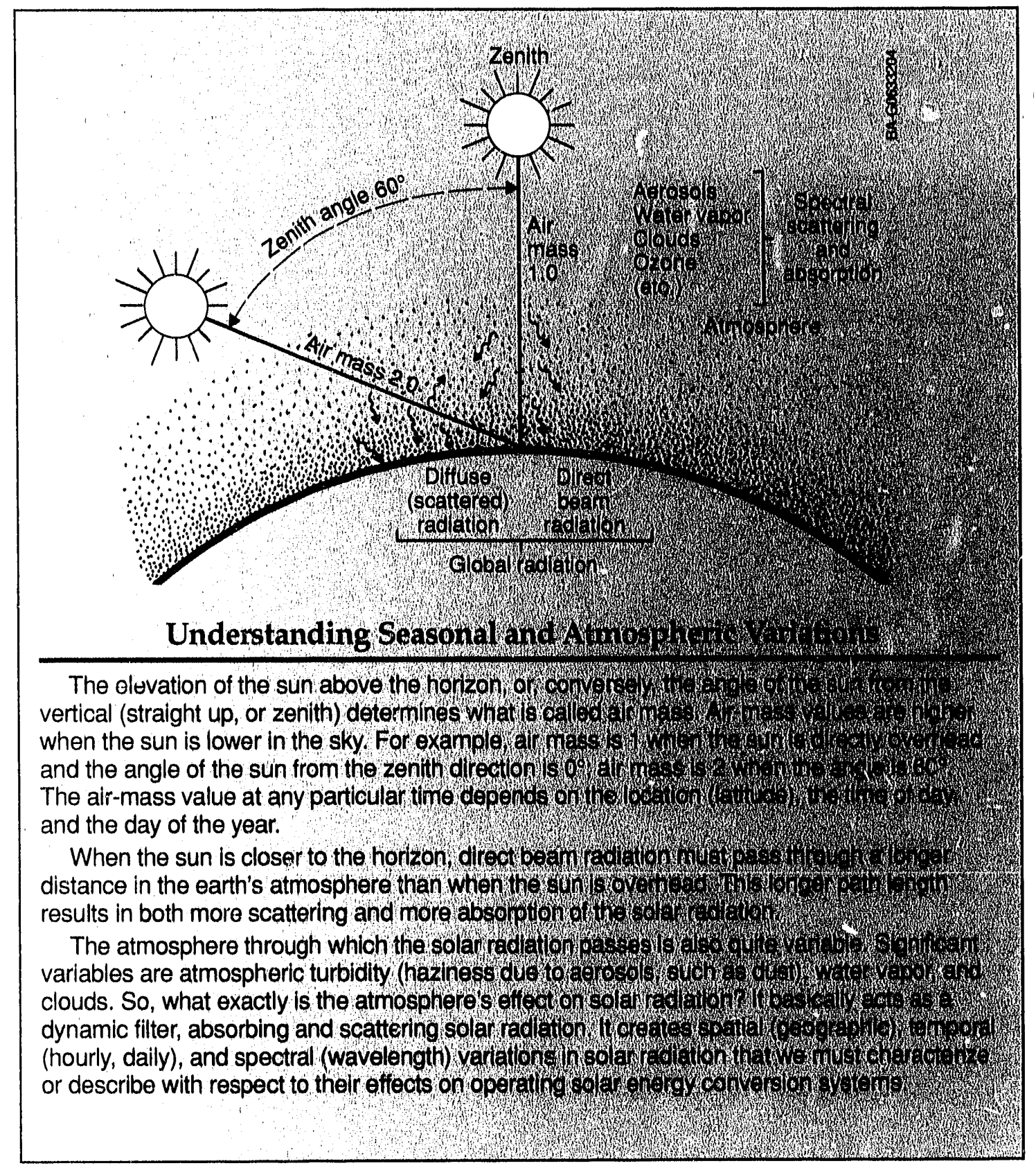

25\%. A large volcanic cruption may

decrease, over a large portion of the earth, the direct beam solar radiation by $20 \%$ and the global solar radiation by nearly $10 \%$ for 6 months to 2 yoars. As the volcanic ash falls out of the atmosphere, the effect is diminished, but complete removal of the ash may take several years. 


\section{hat parts of solar radiation are measured?}

The total or global solar radiation striking a collector has two components: (1) direct beam radiation, and (2) diffuse radiation. Additionally, radiation reflected by the surface in front of a collector contributes to the solar radiation received. But unless the collector is tilted at a steep angle from the horizontal and the ground is highly reflective (e.g., snow), this contribution is small.

As the name implies, direct beam radiation comes in a direct line from the sun.

For sunny days with clear skies, most of the solar radiation is direct beam radiation On overcast days, the sun is obscured by the clouds and the direct beam radiation is zero.

Diffuse radiation is scattered out of the direct beam by molecules, aerosols, and clouds. Because it comes from all regions of the sky, it is also referred to as sky radiation. The portion of total solar radiation that is diffuse is about $10 \%$ to $20 \%$ for clear skies and up to $100 \%$ for cloudy skies.

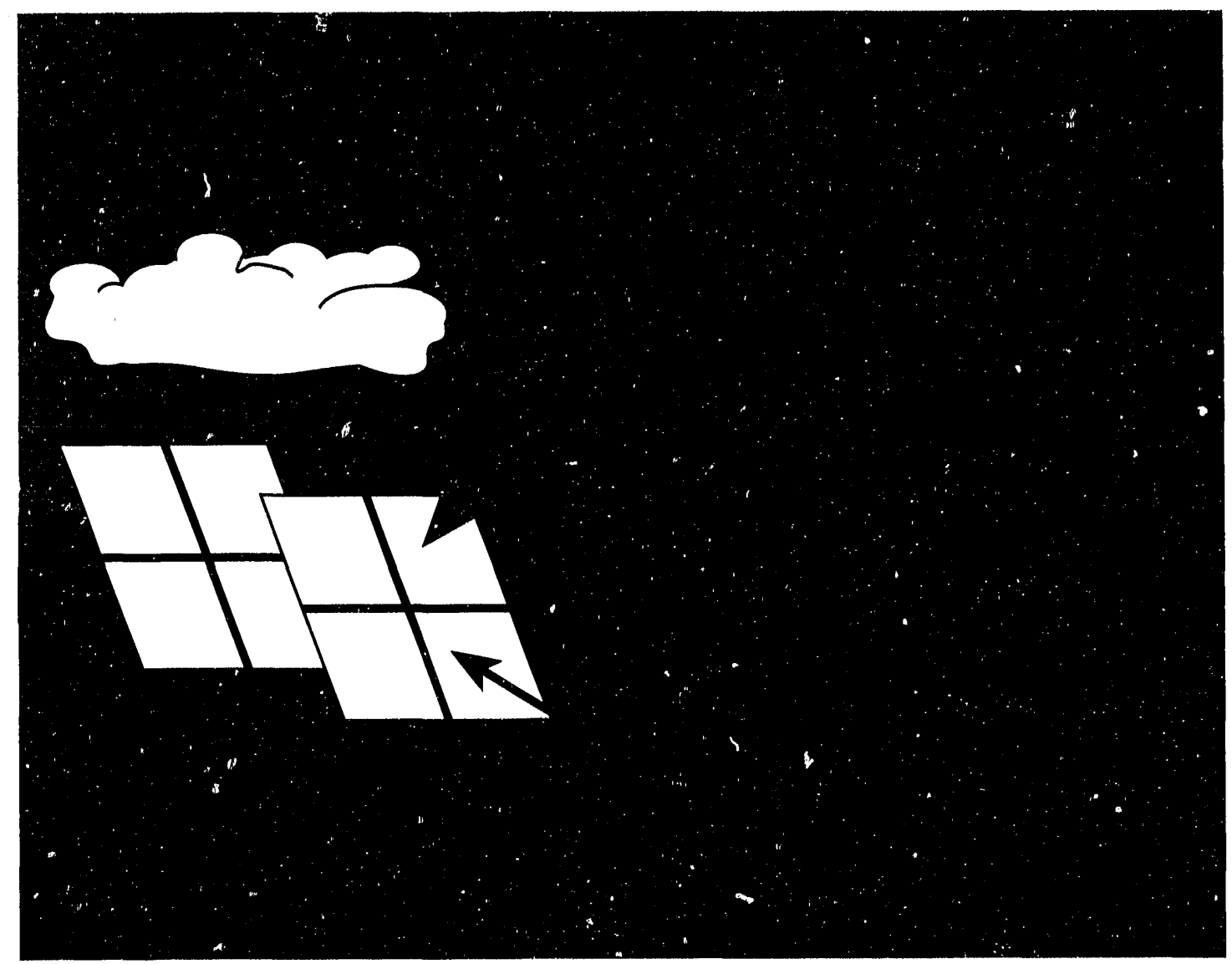

Some of the solar radiation entering the earth's atmosphere is absorbed and scattered. Direct beam radiation comes in a direct line from the sun. Diffuse radiation is scattered out of the direct beam by molecules, aerosols, and clouds. The sum of the direct beam, diffuse, and ground-reflected radiation arriving at the surface is called total or global solar radiation. 
The type of data needed and the funds available help determine the number and kinds of instruments used at a site to measure solar radiation. A complete solar radiation monitoring station has instrumentation for measuring three quantities: (1) total or global radiation on a horizontal surface, (2) diffuse radiation on a horizontal surface, and (3) direct beam radiation. Measuring all three quantities provides sufficient information for understanding the solar resource and for rigorous quality assessment of the data. Any two of the measured quantities can be used to calculate a range of acceptable values for the third. Many monitoring stations also have equipment for measuring solar radiation on tilted and tracking surfaces and for measuring meteorological parameters such as ambient temperature, relative humidity, and wind speed and direction.

A station with a lower level of funding may only measure two quantities; the third is calculated. For example, the direct beam component can be derived by subtracting the diffuse radiation from the global radiation and applying trigonometric relationships to account for the position of the sun. The trade-off for this approach is that the calculated direct beam data are less accurate than if the direct beam data were measured.

Historically, many stations have measured only the global radiation on a horizontal surface. This necessitates calculating both the diffuse and direct beam solar radiation, which results in less accurate values for these two quantities than if they were measured.
In the absence of any soliar radiation measurements, we employ models using meteorolugical data such as cloudiness and minutes of sunshine to estimate solar radiation. Although much less accurate, this is often the only option we have for locations where solar radiation is not measured. Cloudiness data are based on observations by a tiained meteorologist who looks at the sky and estimates the amount of cloud cover in tenths. A clear sky rates a cloud cover value of 0 tenths, and an overcast sky rates a cloud cover value of 10 tenths. Minutes of sunshine are recorded by an instrument that measures the time during the day when the sun is not obscured by clouds.

To investigate the spectral distribution of solar radiation, an instrument called a spectroradiometer measures the solar radiation intensity at discrete wavelengths. Spectroradiometers are complex and relatively expensive instruments, and their operation and maintenance require significant effort. Consequently, spectroradiometers are not routinely used for long-term data collection. Rather, they help establish data bases that have sufficient information to validate models that predict the spectral distribution based on meteorological data and the position of the sun. 


\section{These instruments measure solar radiation:}

a Pyranometer with $180^{\circ}$ field of view measures total or global solar radiation.

b Pyranometer with shadow band measures diffuse solar radiation. The shadow band blocks the direct beam solar radiation so the pyranometer only sees diffuse or sky solar radiation.

c Pyrheliometer mounted on a sun-tracker measures direct beam solar radiation. The pyrheliometer has a narrow field of view and detects radiation coming directly from the sun.

d Rotating shadow band radiometer measures both global and diffuse solar radiation. A motor moves the shadow band to shade the sensor from direct beam solar radiation while diffuse solar radiation is measured. Then the motor moves the shadow band to unshade the sensor while global solar radiation is measured.

e Spcctroradiometer measures the spectral distribution of global solar radiation.
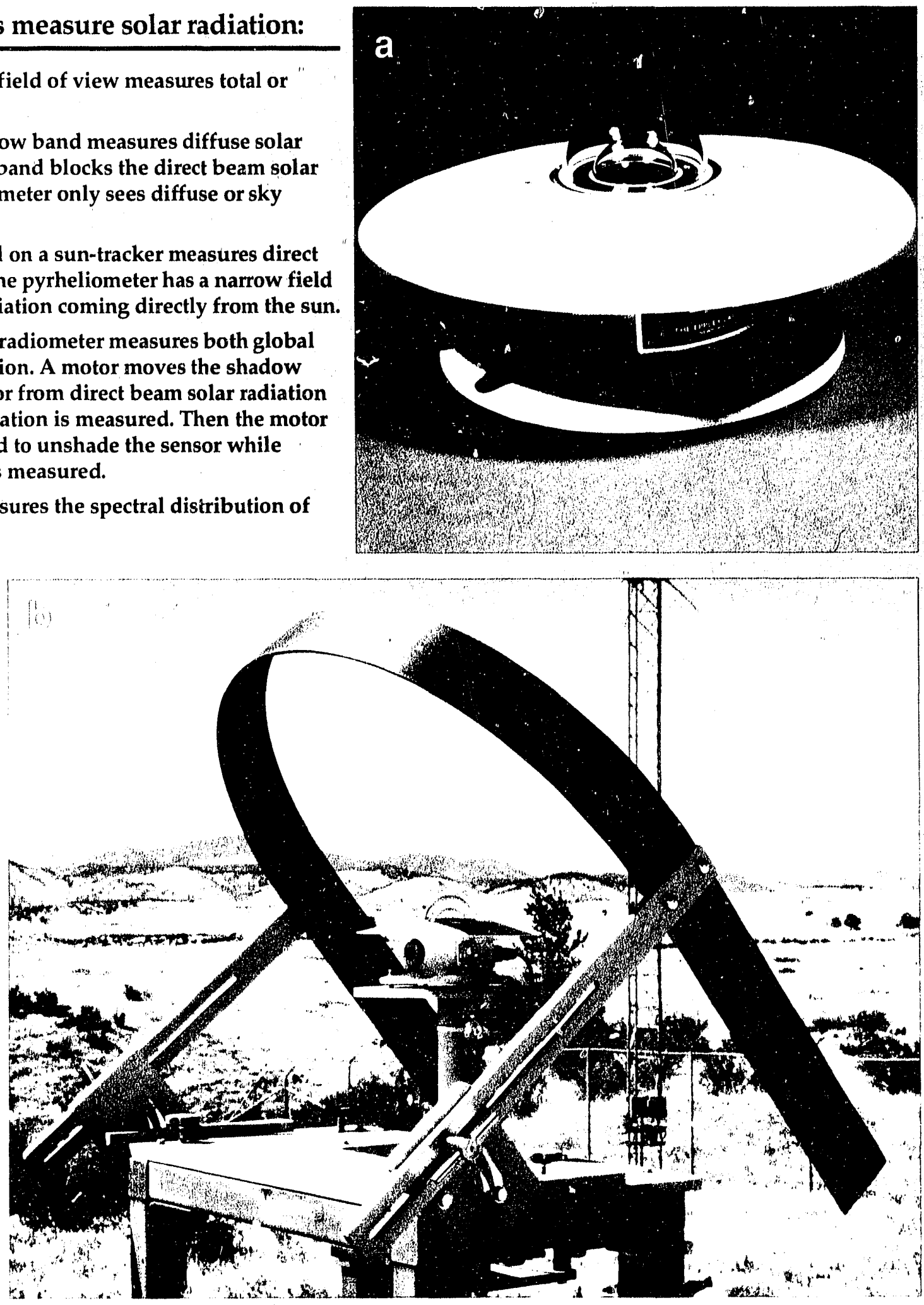

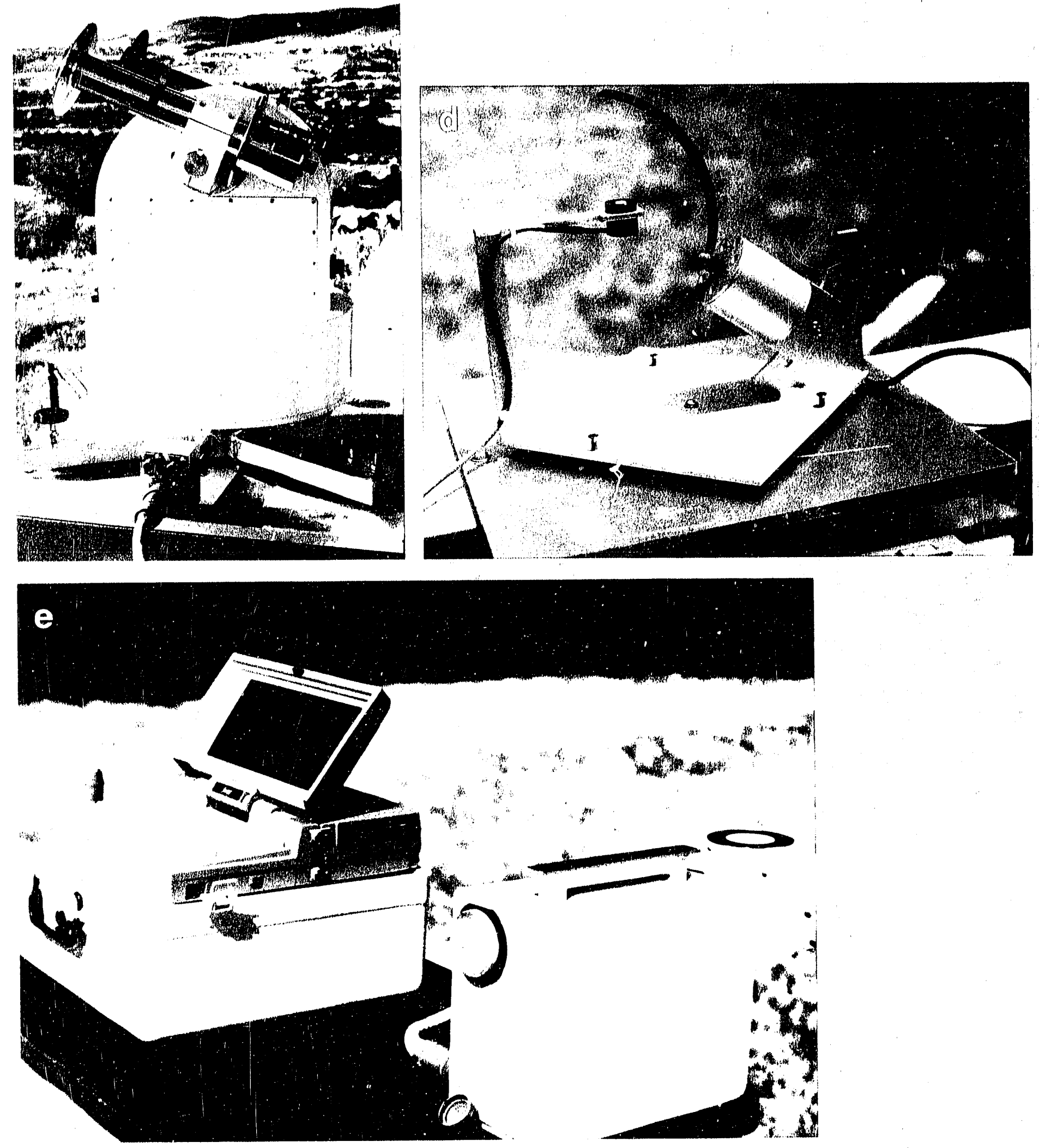


\section{ow do we use solar radiation data?}

Solar energy technologies rely on solar radiation to provide energy for producing electricity, heating water, destroying toxic wastes, and lighting and heating buildings. Common to these technologies is that the end-use product is, for the most part, a direct function of the amount of solar radiation received and the conversion efficiency.

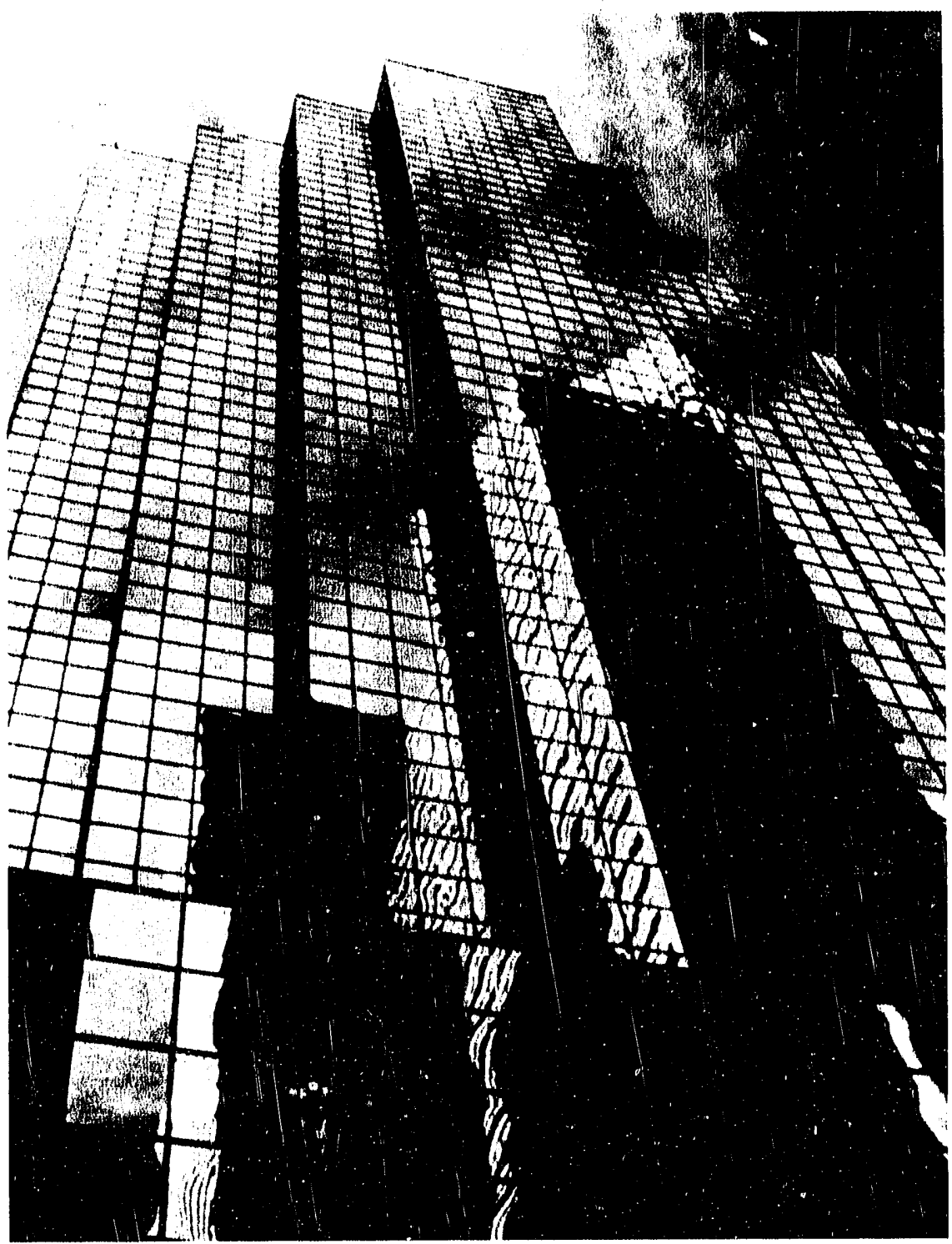

Windows can significantly affect the heating and cooling loads of buildings. Engineers and architects can use solar radiation data to evaluate the effects that windows will have on the energy consumption of a building and hence determine the size of heating and air conditioning equipment needed.
That is, if the amount of solar radiation is increased, then the end-use product increases also. This is also true for solar fuel production, in which crops are grown and then converted into fuels and byproducts. Although dependent on the soil type and rainfall, crops also depend on the amount of solar radiation received.

To determine the performance and economics of solar conversion technologies, designers and engineers use solar radiation data to estimate how much solar energy is available for a site. Depending on the particular technology, the solar collector might be a photovoltaic array, a concentrating parabolic trough, a domestic hot water collector, a window, a skylight, or a canopy of foliage. Designers and engineers use hand calculations or computer simulations to estimate the solar radiation striking a collector.

Hand calculations are appropriate when using solar radiation data that represent an average for an extended period. For example, designers of remote photovoltaic powered systems for charging batteries use average daily solar radiation for the month to determine the size of the photovoltaic array. The criteria for this application is not the amount of solar radiatior for a given hour or day but whether or not the average daily solar radiation for the month is sufficient to prevent the batteries from becoming discharged over several days.

The month used in the design process depends on the relative amount of solar radiation available compared to the energy required by the load. For a system in which the load is constant throughout the year, solar radiation data for December or January are usually used for the northern hemisphere. 
Computer simulations are an effective tool when an hour-by-hour performanoe amalysis is needed. Utility engineers may want to know if the output of a solar electric power plant could reliably and economically help meet their daytime electric demand. (One of the potential benefits of a solar electric power plant is that its output may coincide with the utility peak electric demand for summertime air conditioning loads.) By using the hourly solar radiation data for its location, the utility can run computer programs that show how much energy could be produced on an hour-by-hour basis throughout the year by the solar electric power plant.

Some solar energy conversion technologies require a threshlold value of solar radiation before certain operations can begin or be sustained. As an example, a central receiver solar thermal electric power plant may require direct normal solar radiation values above $450 \mathrm{~W} / \mathrm{m}^{2}$ to produce steam for the turbine generator. Consequently, to evaluate a site's potential for solar thermal electric production, a designer examines the solar radiation data to determine the times of day when the solar radiation exceeds the threshold value.

Heating and air conditioning engineers use solar radiation data to optimize building designs for energy efficiency. For example, window orientation and size can affect, the heating and cooling of the building. South-facing windows transmit solar energy in the winter that is beneficial in reducing heating requirements. But in the summer, solar energy transmitted through windows (primarily those that face east or west), must be offset by increased operation of the air conditioning system. By having access to solar radiation data for their location, engineers and architects can evaluate the effects of window orientation and size

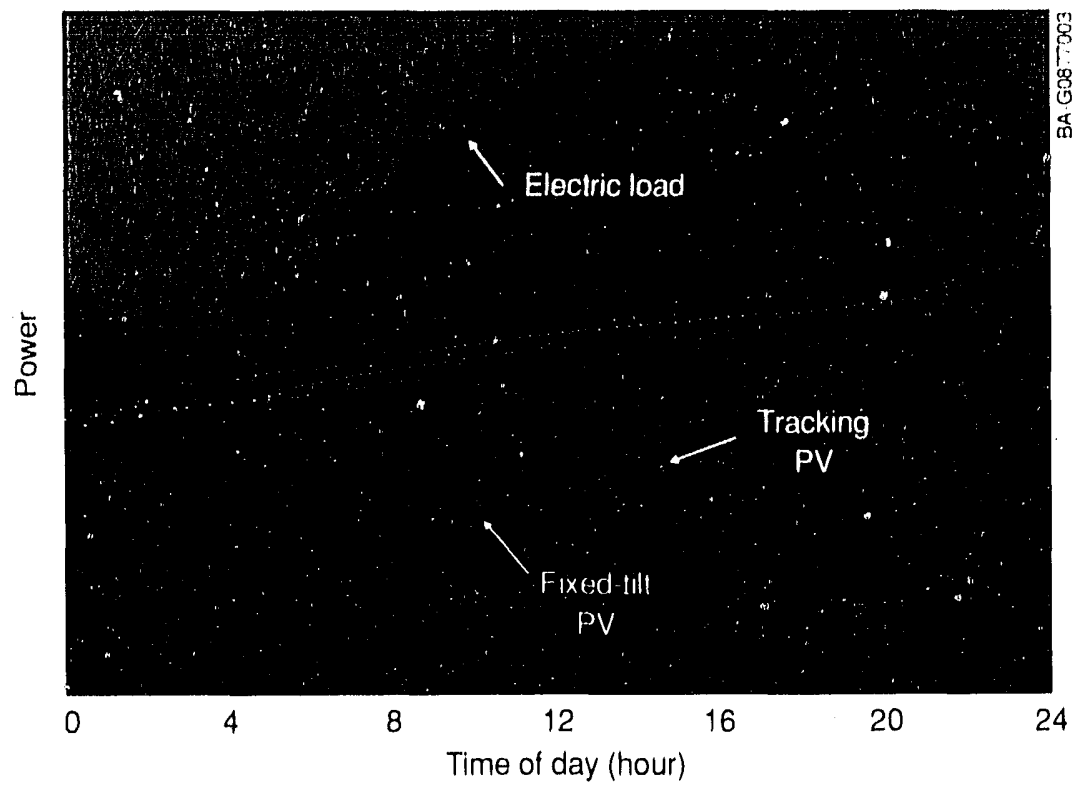

Computer simulation using solar radiation data shows how the output of two photovoltaic power systems could be added to the utility's generation to help meet peak electric demand in the summer. The fixed-tilt array faces south and is tilted from the horizontal at an angle equal to the site's latitude. The tracking array uses motors and gear drives to point the array at the sun throughout the day. Depending on location, the photovoltaic system with the 2-axis tracking array receives annually $25 \%$ to $40 \%$ more global solar radiation than the fixedtilt photovoltaic system and provides more power for longer periods. This must be weighed against the higher initial cost and maintenance required for the tracker.

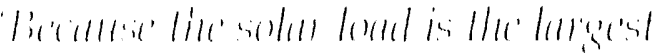

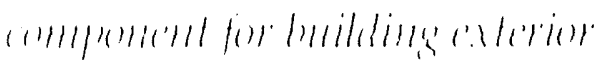

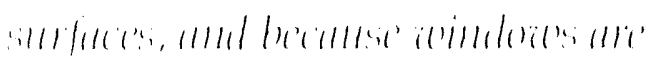

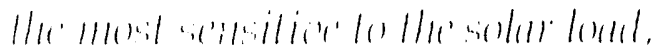

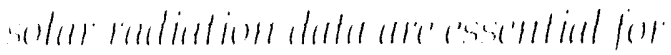

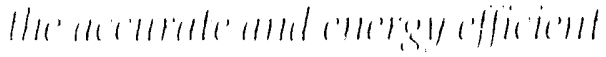

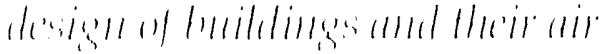

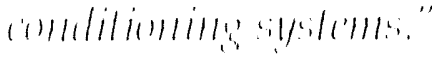

Jack F. Roberts, P.E. American Society of Heating, Refrigerating and Air-Conditioning Engineers 

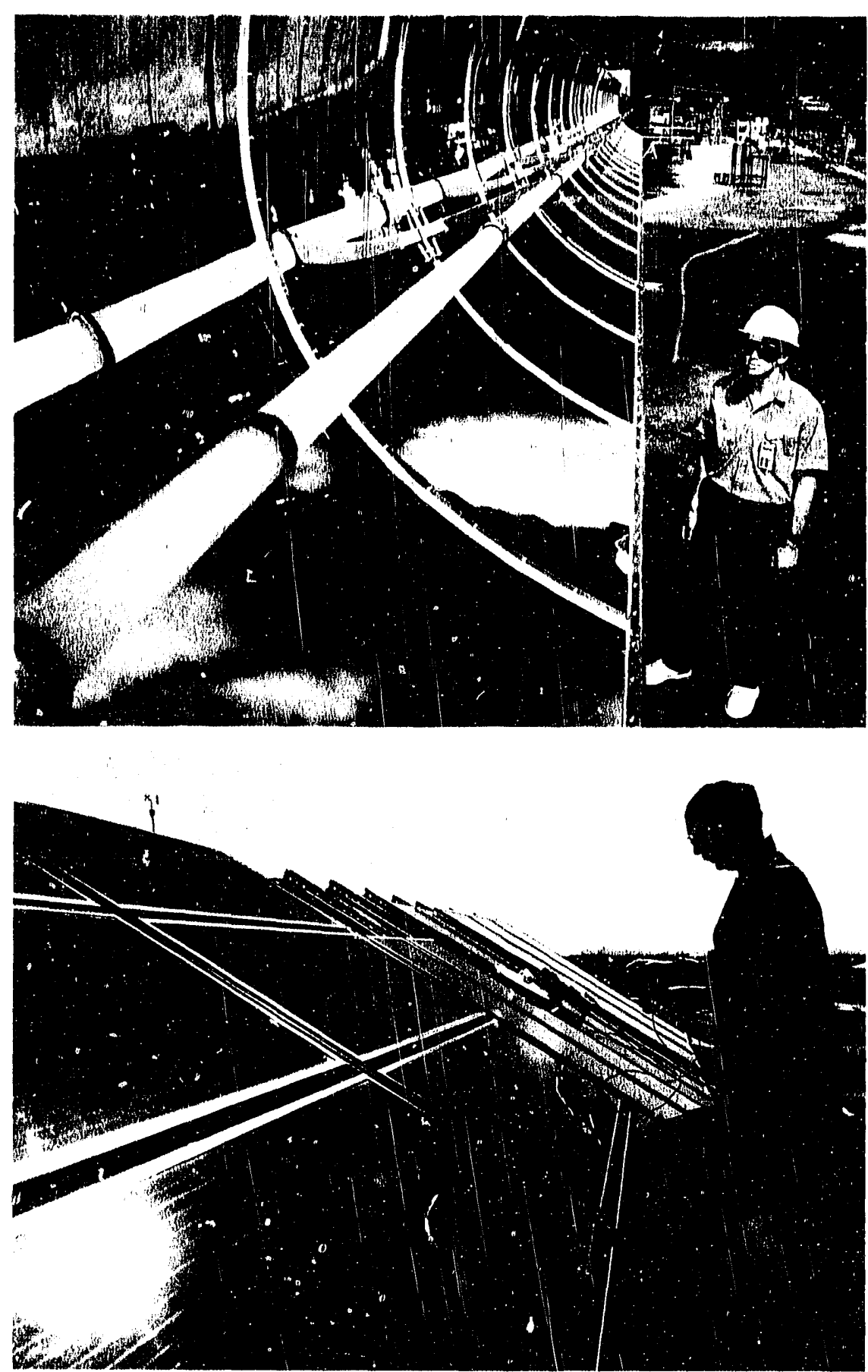

('incentritor collectors (top) use direct beam solar radiation; flat-plate collectors (bottouil) use direct beam radiation, diffuse (sky) radiation, and ground-reflected radiation.

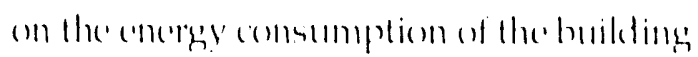
and cletermine the size of the hesting and air conditioning expuipment nexded. They (all) use this informoltion, combined wilh desired levels of maldrial lighting and the building asestherison, lof formulate the fimal huilding dosignt

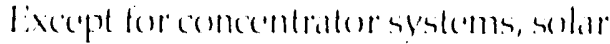

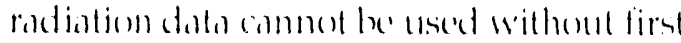
acoumting for the orientation of the solar collectere concentrators track the sum and focus only direct beam radiation, bul flat-

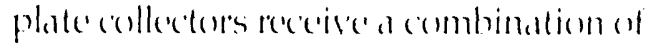
direct beam radiation, diffuse (sky) radialtion, and radtiation reflextert from lhe ground

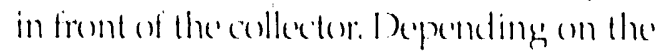
direction the collecter is facing and its tilt from the herizomblal, flat-phole collecters received different amosents of direce berm radiation, diffuse radiation, and groundreflected radiation. Designersemplom equations to calculate the total or gh/obal radiation on a flat-phate collecters. 'The eypations use values of the dired beame radtiation, the diffuse radialiom on a horizontal surface, and the orientation of the collectur.

Tor maximise the amount of endar radistion receved during the verst, flat-plate collectors in the northern hemisphere face south and tilt from the horigomlal at an angle approximately expul to the site's latitude. The ammual energy production is not very sensitive to the tilt angle as longs as it is within plus or minus $15^{\prime \prime}$ of the latitude. As a general rule, lo optimize the performance in the winter, the collectere com be tilted 15 " grenter than the latitude. Io optimise performanee in the summer, the G Hectere con be tilted 15 "less than the latitude. Solar radiation data combined with computer simulations cond define these relationships more precisely.

In the initiol design stage, designers of colls used in photovoltaic modules con use spectral solar radiation data bases and 
models lo optimize the cells for maximum energy preduction. Becouse the spectral content of solar radiation changes throughout the day and scasom, photovoltaic cells are hilored for a specific range of solar ractiation wavelengths that will produce the most encrgy. Different photovoltaic materials have different peak responses; performance models using spectral solar radiation data bases can compare two or more photeveltaic materials operating under a range of seasons and climates. This results in optimizing the design early and eliminates the expense and time that would otherwise be needed for prelimin-

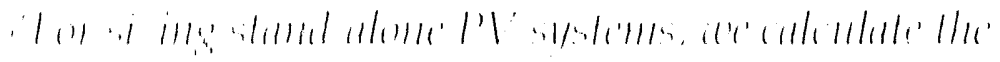

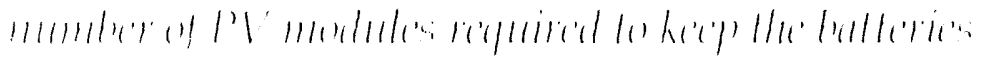

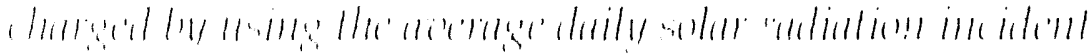

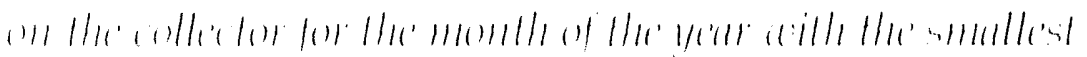

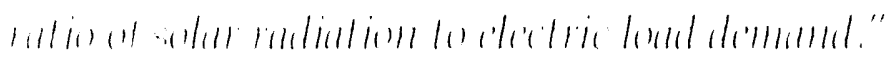

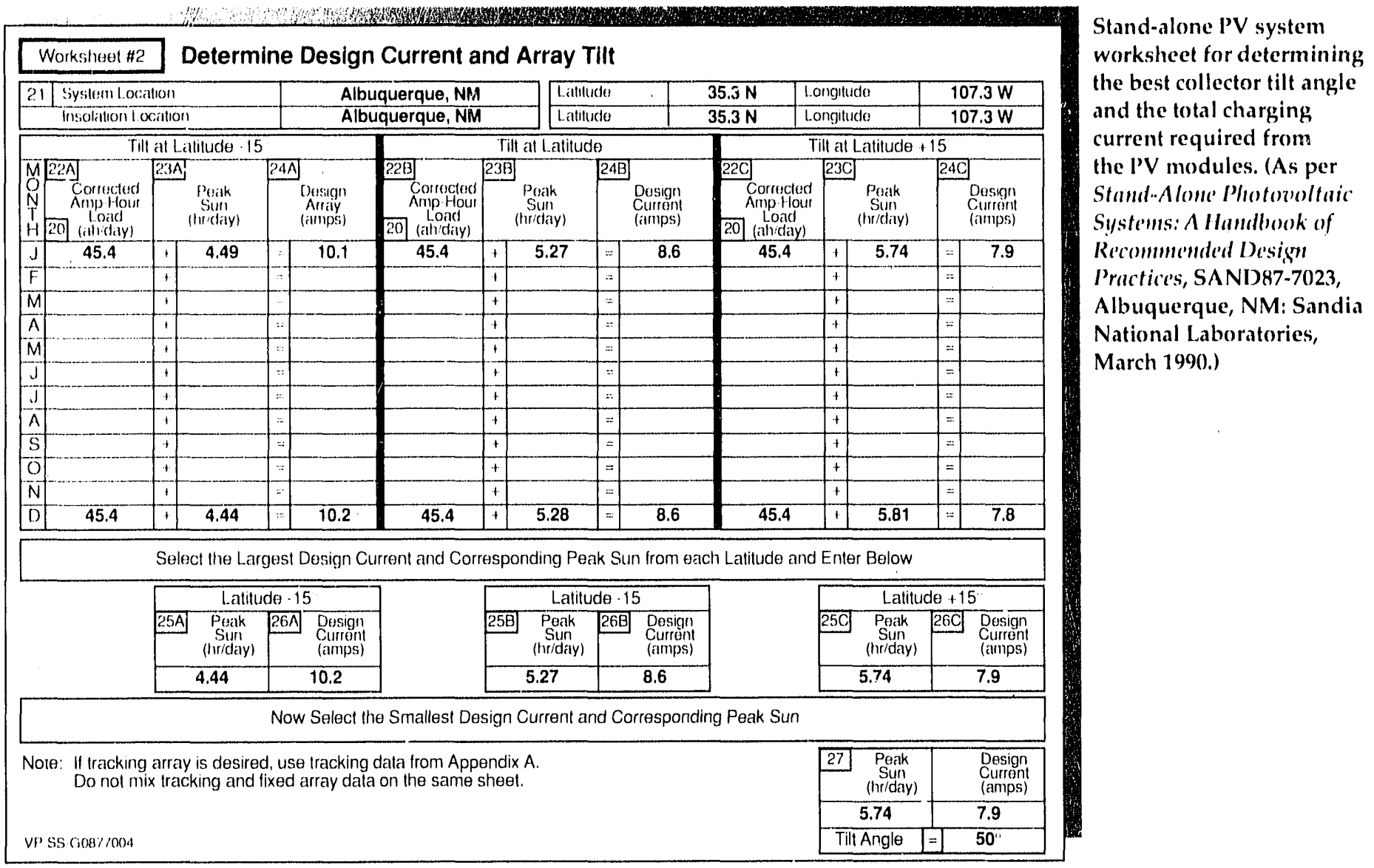




\section{here can you obtain solar radiation data?}

The National Weather Service of the

National Oceanic and Atmospheric

Administration (NOAA) operates monitor-

ing stations in the United States to collect and disseminate information about solar radiation. This information is available on computer readable magnetic tape from $N() \wedge \wedge^{\prime} s$ National Climatic Data Center (NCDC), Federal Building, Asheville, NC. 288() 1 (7()4) 259-()682.

Most of NOAA's solar radiation data sets are from 26 SOLMET stations and 222 ERSATZ stations and consist of hourly values of solar radiation and meteorological data from 1952 to 1975 . For the SOLMET stations, instruments measured the global horizontal solar radiation and researchers modeled the direct beam solar radiation dati. For the ERSATZ stations, although no solar radiation measurements were made, rescarchers modeled global horizontal radiation based on observed meteorological data such as cloudiness and minutes of sunshinc; the ERSATZ data do not include direct beam radiation. Because all the ERSATZ data are modeled, these data are less accurate than the SOLMET data.

NOAA also has available more recent data for the periods 1977 to 1980 and 1988 to the present. The data include hourly values of measured global horizontal solar radiation for 38 stations, measured direct beam solar radiation for 32 stations, and measured diffuse horizontal radiation for nine stations.

Two of NOAA's data sets are of particular interest to designers and engineers: the typical meteorological year (TMY) data set and the weather year for energy calculations (WYEC) data set. For these, researchers extracted information from SOLMET/ ERSATZ data to make data sets of hourly values spanning one year. For the ERSATZ

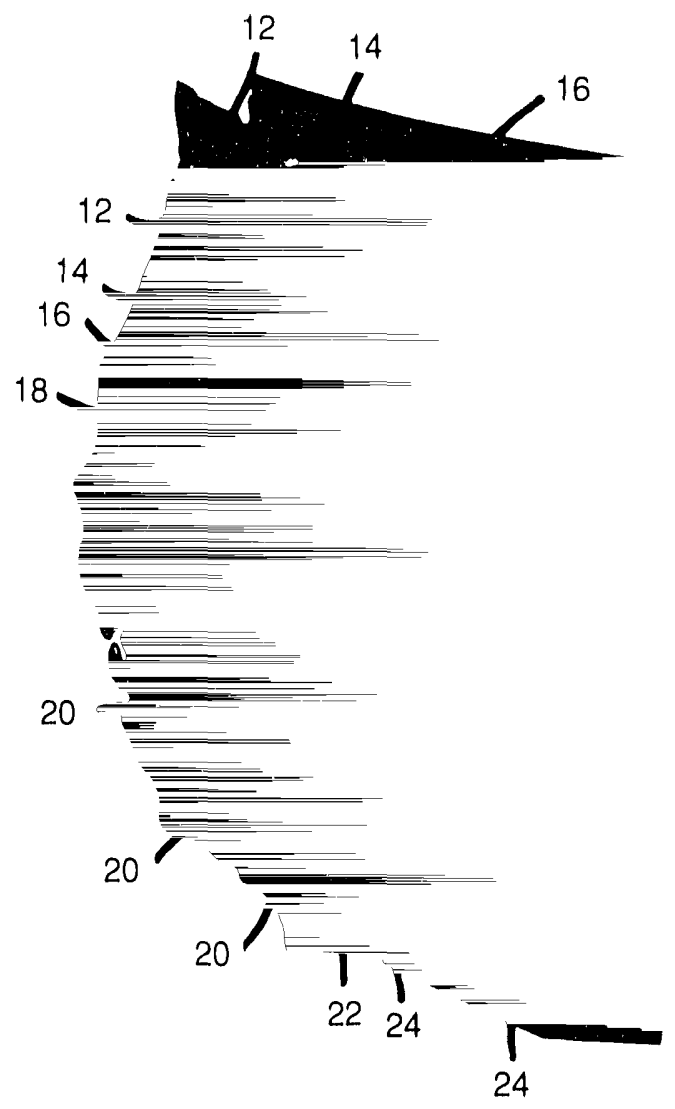

TMY data, researchers included values of direct beam radiation with modeled values of global horizontal radiation. These data sets represent typical values occurring from 1952 to 1975, and not the minimum or maximum values. For example, a cloudy year in this period may have had an annual solar radiation value $10 \%$ below the TMY value, and a very cloudy month in this period may have had a solar radiation value $40 \%$ percent below its TMY value. A difference between TMY and WYEC data is that the TMY datio are weighted toward solar radiation values and their hourly distribution, whereas the WYEC data are weighted toward average monthly values of temperatures and solar radiation. Researchers recently revised the WYEC data to include estimates of direct beam and diffuse solar radiation 


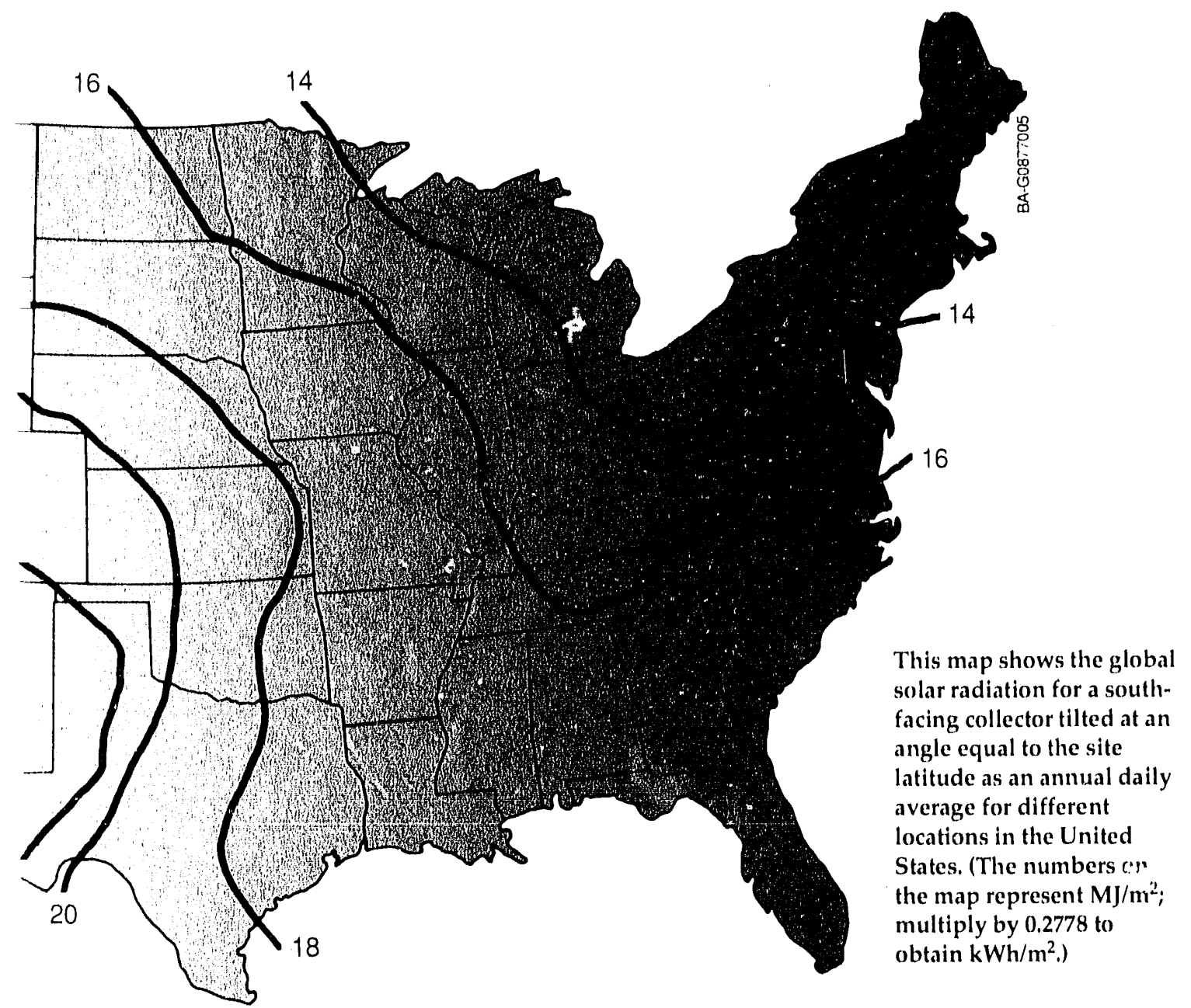

and estimates of illuminance for lighting applications. Illuminance refers to solar radiation in the visible region of the solar spectrum to which the human eye responds.

Solar radiation data derived from the SOLMET/ERSATZ data sets are also published in tabular form by the National Technical Information Service (NTIS), U.S. Department of Commerce, 5285 Port Royal Road, Springfield, VA 22161. Two of these tabular data sets are listed below.

Insolntion Data Manual and Direct Normal Solar Radiation Datn Mamual, SERI/TP-2203880, Golden, CO: Solar Energy Research Institute, July 1990.
This manual contains monthly averages of global horizontal and direct beam solar radiation, ambient temperature, the ratio of global horizontal solar radiation on earth to that outside the earth's atmosphere $(\mathrm{Kt})$, and heating and cooling degree-days. This information is presented for all the SOLMET/ERSATZ stations.

Stant-Alone Plotoroltaic Systems: A Handbook of Recommended Design Practices, SAND87-7()23, Albuquerque, NM: Sandia National Laboratories, March 1990.

The appendix of this handbook contains monthly estimates of solar radiation striking collectors. These estimates are calculated for different tilts and sun-tracking 


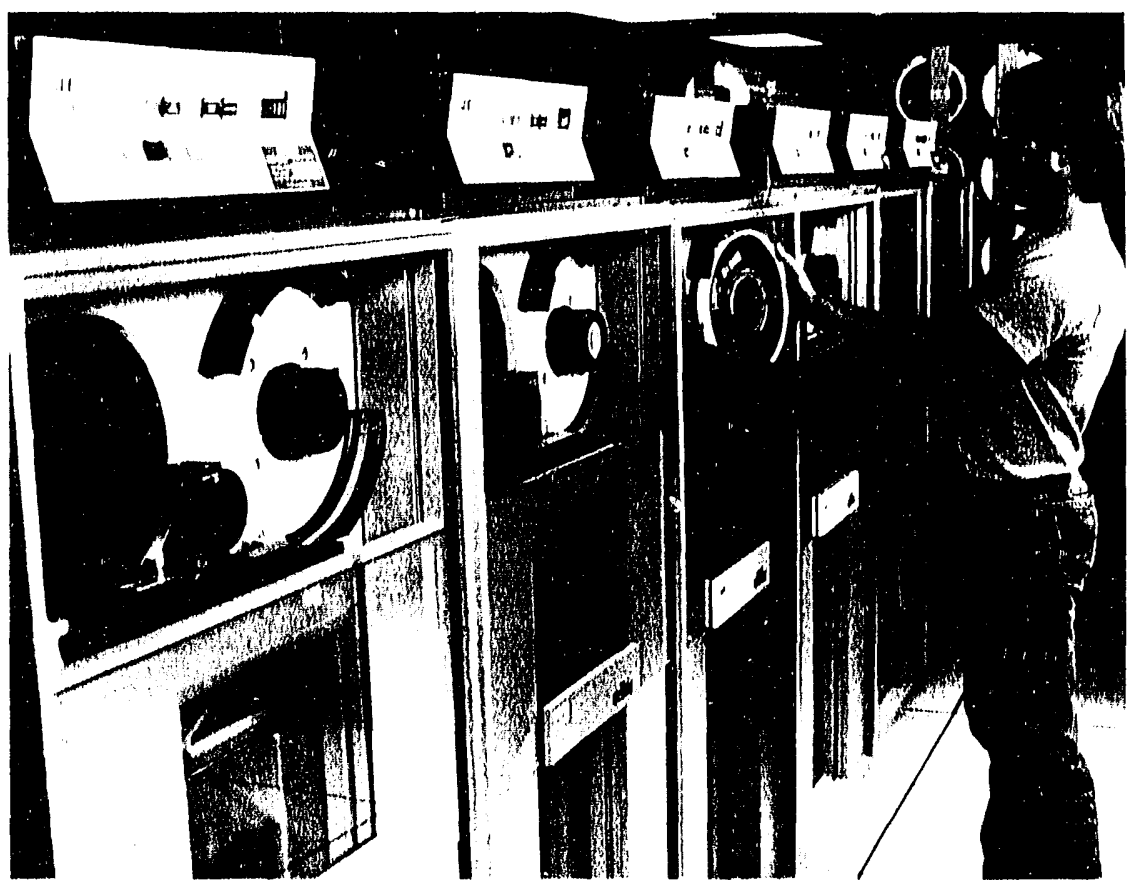

No $\Lambda \Lambda^{\prime} s$ National (limatic Dala Center has solar radiation data avallable on computer readable magnetic lape. The data sets are for 26 SOLMLT stations and 222 I:RSATY stations and consist of hourly values of solar radiation and meteorological dala from 1952 lo 1975.

schemes. The estimatess are for a solected sot of 38 SOLMLT/ERSAT"Z, stations and are based on the S()LMET/ERSATZ data.

Maps are avialiable that depict long-term average solar radiation data for each month. This is a convenient way to show variations in the amount of solar radiation and for inlerpolating data between stations. For the United States, these maps were made using solar radiation data from the SOL MET/ ERSATZ data base. The Soller Rudiution

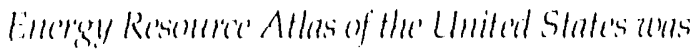
published by the Superintendent of Documents, but is out of print. This atlas is available at some university and city libraries.

The University of lowell compiled an intermational solar radiation data base for locations outside the United States. This data base presents average daily values by month and year for global horizontal solar radiation. It is available from the University of lowell l'hotovoltaic l'rogram, 1 University Avenue, Lowell, MA ()1854 (5)8) 9.34-3.377.

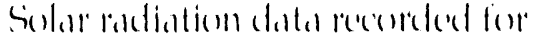

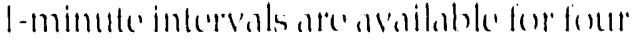
locillons: Alhamy, Now' York; Allumlar,

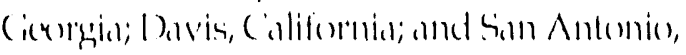

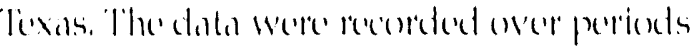
of I year or more by university moterorologi-

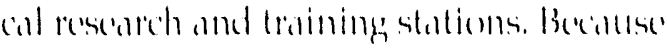

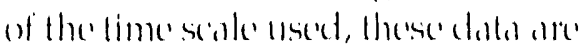

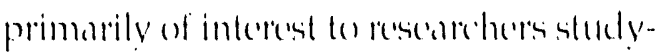

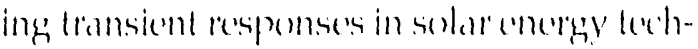

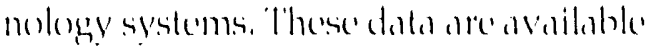
from the Notional Renowable linergy

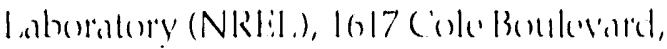
Ciolden, (i) $8(1) 4())$

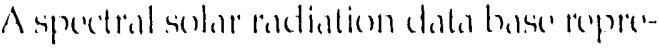
sonting a ronge of atmospherice and climatic comblitions is also avalable from NRE!l. This dalia baste includes more than .3(0)()

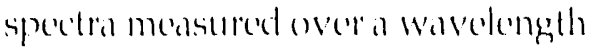

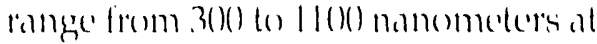
2-monomomere increments (I nomomotere is once-billionthof a metere and is the result of a conperative effort between NRI:L, the bilectric l'ower Resesarch lnstitule, the filoricla Solar linergy ('entere and the l'acific (iats and likectric Company Spectrial solar radiation was measured at there sites: (ape Canaveral, filorida; San Ramon, California; and Denver, (olorado, This data base can help determine whether spectrally selective technologies (stcth as photovoltaics and biomass) are optimized for a particular locition and climate.

Additiomally, other soureses of soldar matiation data are strate and locial govermments, utilities, and universitics. Examples include the Pacific (ian and Electric Solar Insolation Moniloring I'rogram, the University of ()regon/Pacific Northwest Solar Radiation Data Network, and the I listorically Black Colleges and Universities Solar Radiation Monitoring Notwork. 


\section{ow accurate do the data need to be?}

The reculuired accuracy of the solar radiation data for a site depends on the application.

When the cost of the solar conversion device is low compared with the overall system cost, we can account for uncertainties in the solar radiation data by using "engincering judgment" to increase the size of the solar collectors. However, as the

\section{J.E. Blgger \\ Electrlc Power Research Institute}

solar energy conversion system increases in size and cost, this becomes less acceptable, and we need more accurate solar radiation data to optimize the design and project the cost.

For large-scale applications of solar energy conversion technologies, must experts agree that solar radiation data should be accurate to within $5 \%$ so they can make reasonable assumptions concerning energy output to evaluate the performance and economics. Unfortunately, not much available solar radiation data are accurate to within 5\%. This is due to the measurement uncertainties of the instruments used and the limited number of measurement sites. Consequently, designers teday have to apply these data more conservatively than is ultimately desirable.

The SOLMET / ERSATZ data are the most widely used solar radiation data. On an average for all sites, they are accurate to within about $10 \%$ for average daily values on an annual basis, But for average daily values on a monthly basis for an individual site, they can be in error by $20 \%$ or more. For interpolating data for sites between SOLMET/ERSATZ stations, microclimate differences due to terrain and local weather conditions can also increase the uncertainty of the dala.

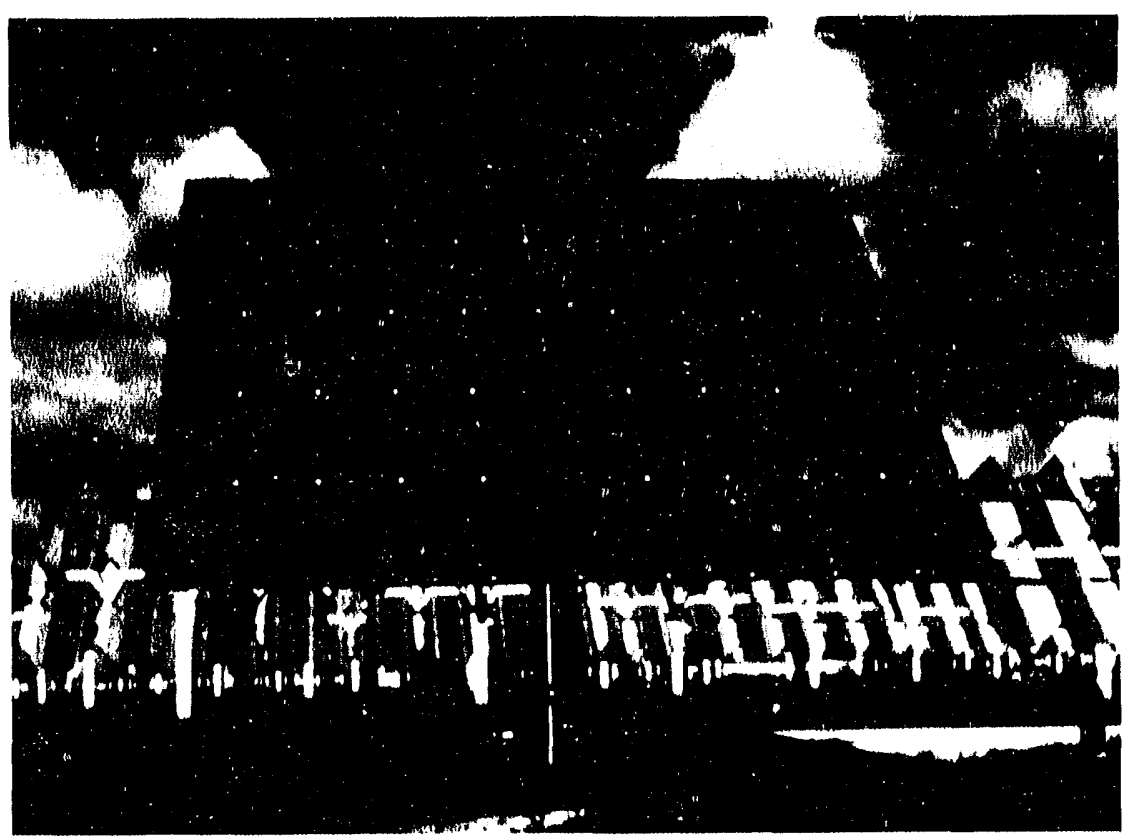

For large-scale applications, like this 6.5-MW photovoltaic system, designers prefer solar radiation data that are accurate to within $5 \%$ so they can make sound assumptions concerning system output, performance, and economics. (Photo courtesy of Siemens Solar Industries.) 


\section{ow will we meet our solar radiation data needs?}

One of the goals of the Solar Ractiation Rescource Assessment Project at NREL is to provide accurate information about solar radiation $t$ o minimize the economic risk of implementing solar energy conversion technologies. The data must accurately represent the spatial (geographic), temporal (hourly, daily, and seasonal), and spectral (wavelength distribution) variability of the solar radiation resource at different locations.

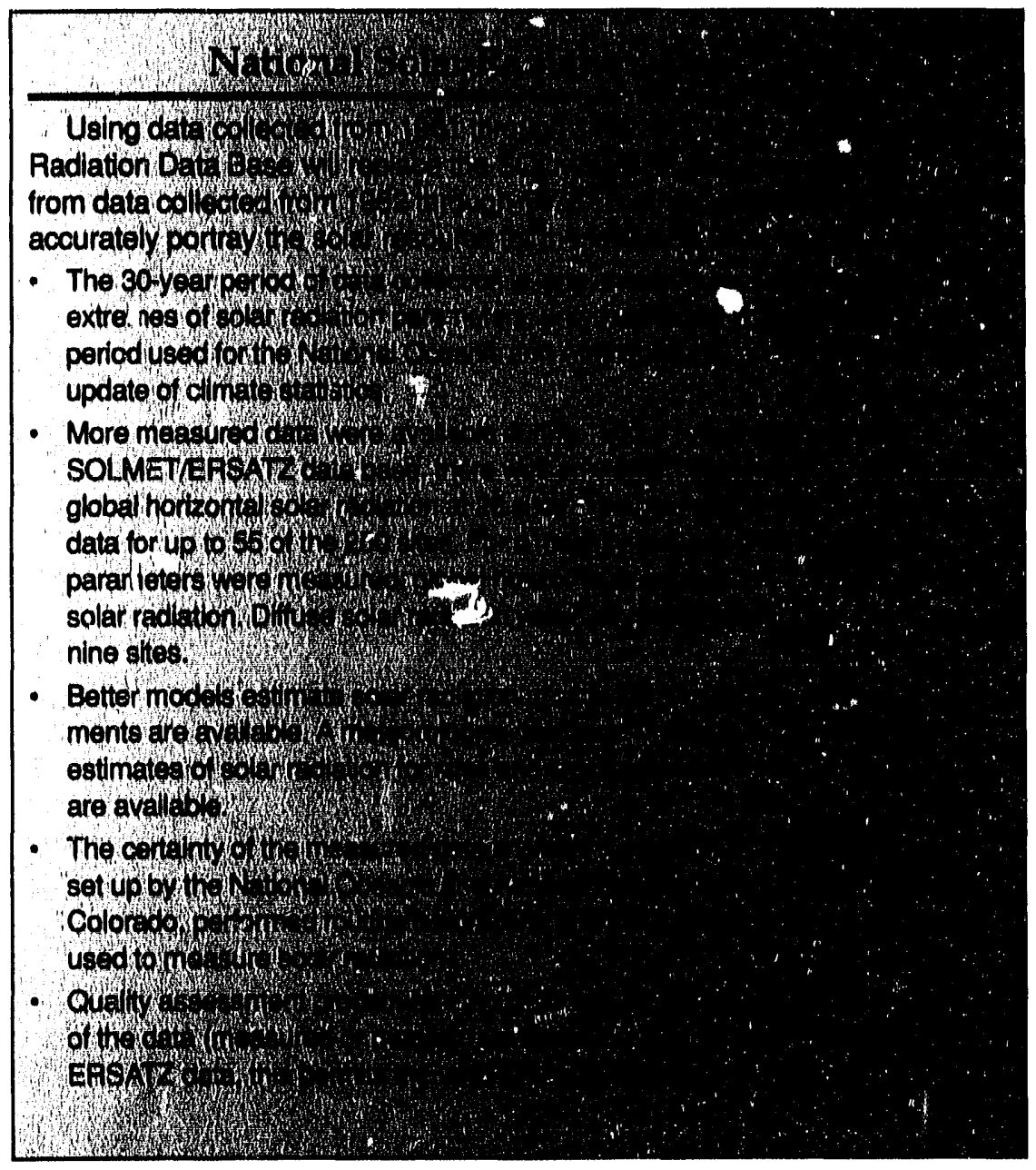

The new National Solar Radiation Data Base (1961-1990) for the United Slates will improve data quality over the extsting SOLMET/ERSATZ (1952-1975) data base. For this new data base, NOAA used better equipment for measuring solar radiation at more sites and NREL used better modeling techniques for synthetic stations.

Scheduled for completion in 1992, this new data base will include data for 250 sites. After completing the data base we will produce special purpose products such as typical meteorological year (TMY) data sets, maps, and data summaries.

By continuing the long-term measurement of solar radiation at numerous sites, we can assess changes in climate and add new data to existing data bases. We can improve the quality of the solar ractiation data base for the United States by working with existing regional solar radiation networks and establishing educational initiatives so that data are being collected at several hundred sites in the United States. This large number of measurement sites will improve the quality of the solar radiation data base, better represent the geographic distribution of solar radiation in the United States, and provide research data to develop techniques to estimate solar radiation where there are no measurement stations.

This type of research involves developing spatial interpolation techniques, such as mapping solar radiation using cloudcover information from satellites, to estimate solar radiation between measurement stations. This cloud-cover mapping technique promises high spatial resolution for the optimum siting of solar energy conversion technologies and enables estimating solar radiation for countries where no solar radiation data base exists. 
NREL is improving the equipment and technicuess used to measure soliar radiation and the models and methods used to determine the performanee of solar conversion technologies, Our recent activities include:

- angular response characterization and uncertainty analysis of solar radiometers,

- development of improved quality assessment procedures for solar radiation data,

- calibration of radiometers for industry and members of the scientific community,

- development of both broadband and spectral soliar irradiance models, and

- contributions to the development of solar trackers and spectroradiometers. for information about solar radiation datil, models, and assessments contact the NREL Technical Inquiry Service at 3(1).3/2.31-7.3(1).

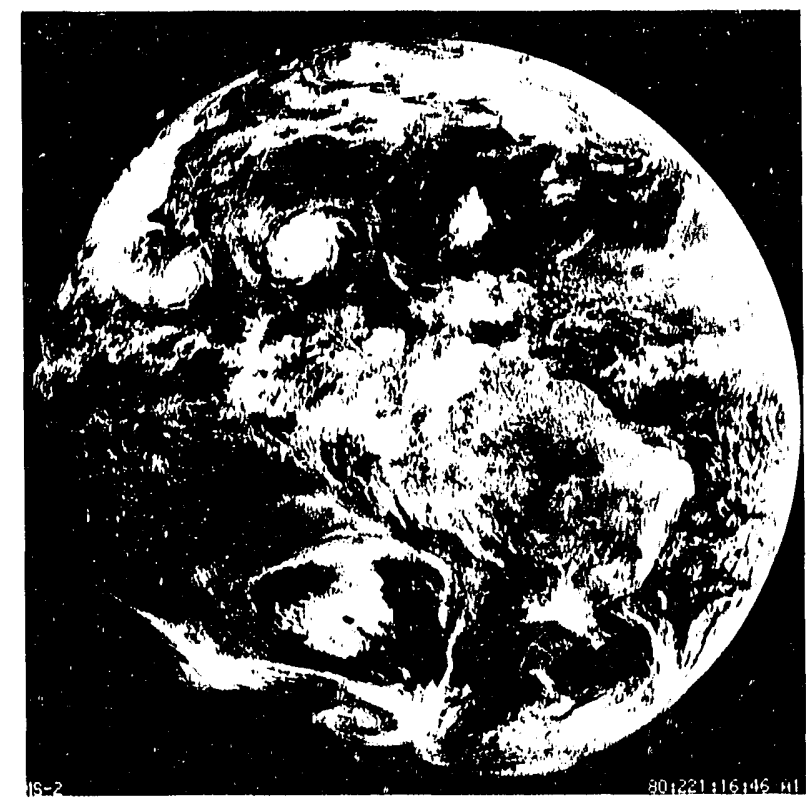

Cloud-cover information, analyzed from photographs taken by satellites, has the potential for estimating solar radiation at any location on earth.

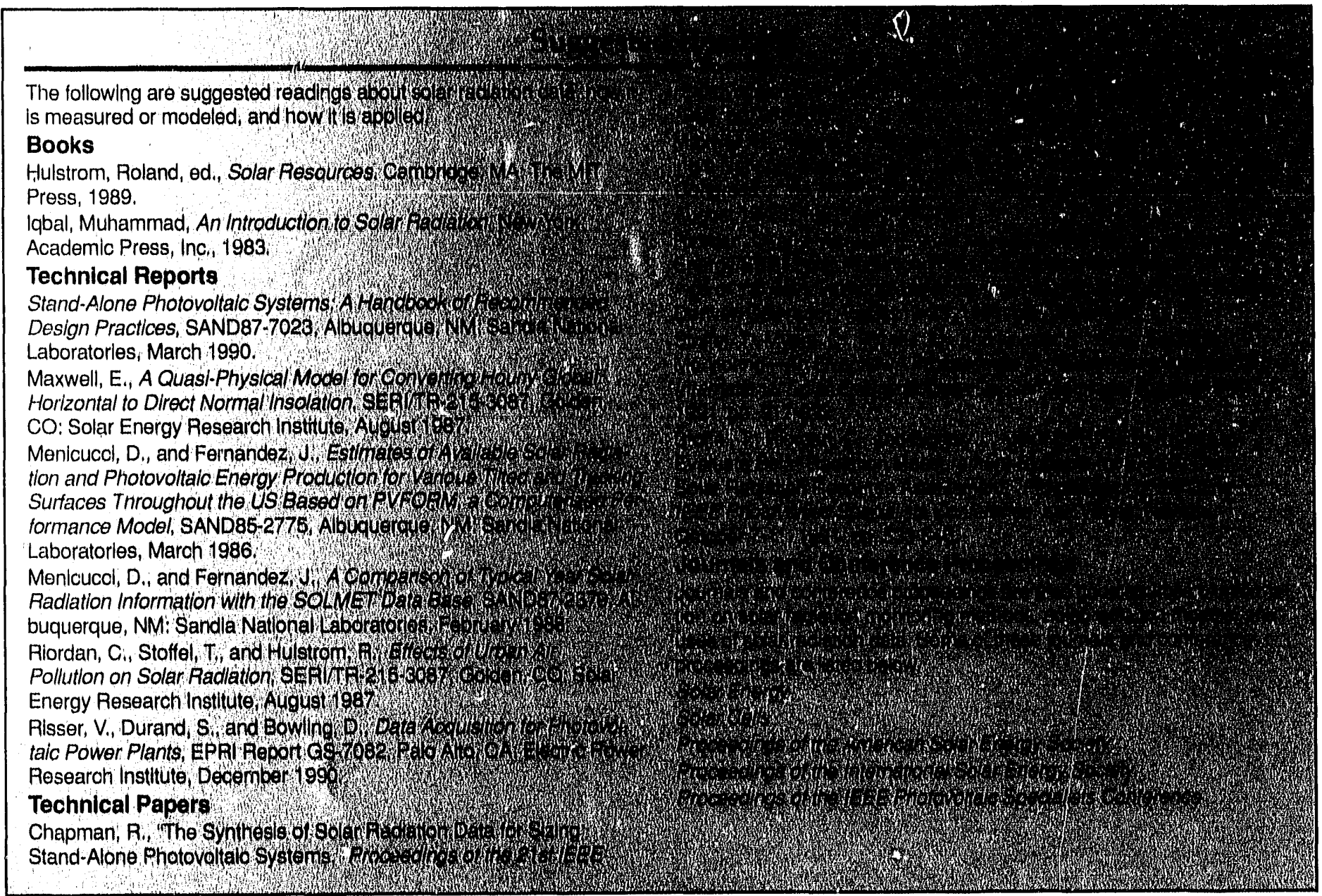




\section{Acknowledgments}

Authors: Blll Marlon, Carol Rlordan, and David Rennè Editors: Mary Anne Dunlap and Gary Cook Design: Susan Sczepanskl and Gary Cook Typography and layout: Susan Sczepanski

This primer was produced by the Development and Communications Office at the National Renewable Energy Laboratory (NREL) for NREL's Solar Radlation Resource Assessmient Project and for the U.S. Department of Energy (DOE). We would like to thank Michael Pulscak (Manager, DOE's Resource Assessment Program) for his support and guidance. We would also like to thank David Menicucci (Sandla), Richard Chapman (Sandia), Jack Roberts (American Soclety of Heating, Refrigerating, and AirConditloning Engineers), John Blgger (Electric Power Research Institute), Jim Augustyn (Augustyn \& Company), and Roland Hulstrom (NREL) for their contributions to the primer and for their review.

Notice: This report was prepared as an account of work sponsored by an agency of the United States government. Neither the United States government nor any agency thereof, nor any of their employees, nakes any warranty, express or implled, or assumes any legal liabllity or rosponsibility for the accuracy, completeness, or usefulness of any information, apparatus, produot, or process disclosed, or represents that its use would not infringe privately owned rights. Reference herein to any specific commercial product, process, or service by trade name, trademark, inanufacturer, or otherwise does not necessarily constitule or imply its endorsement, recommendation, or favoring by the United States government or any agency thereot. The views and opinions of authors expressed herein do not necessarlly state or reflect those of the United States government or any agenoy thereot.

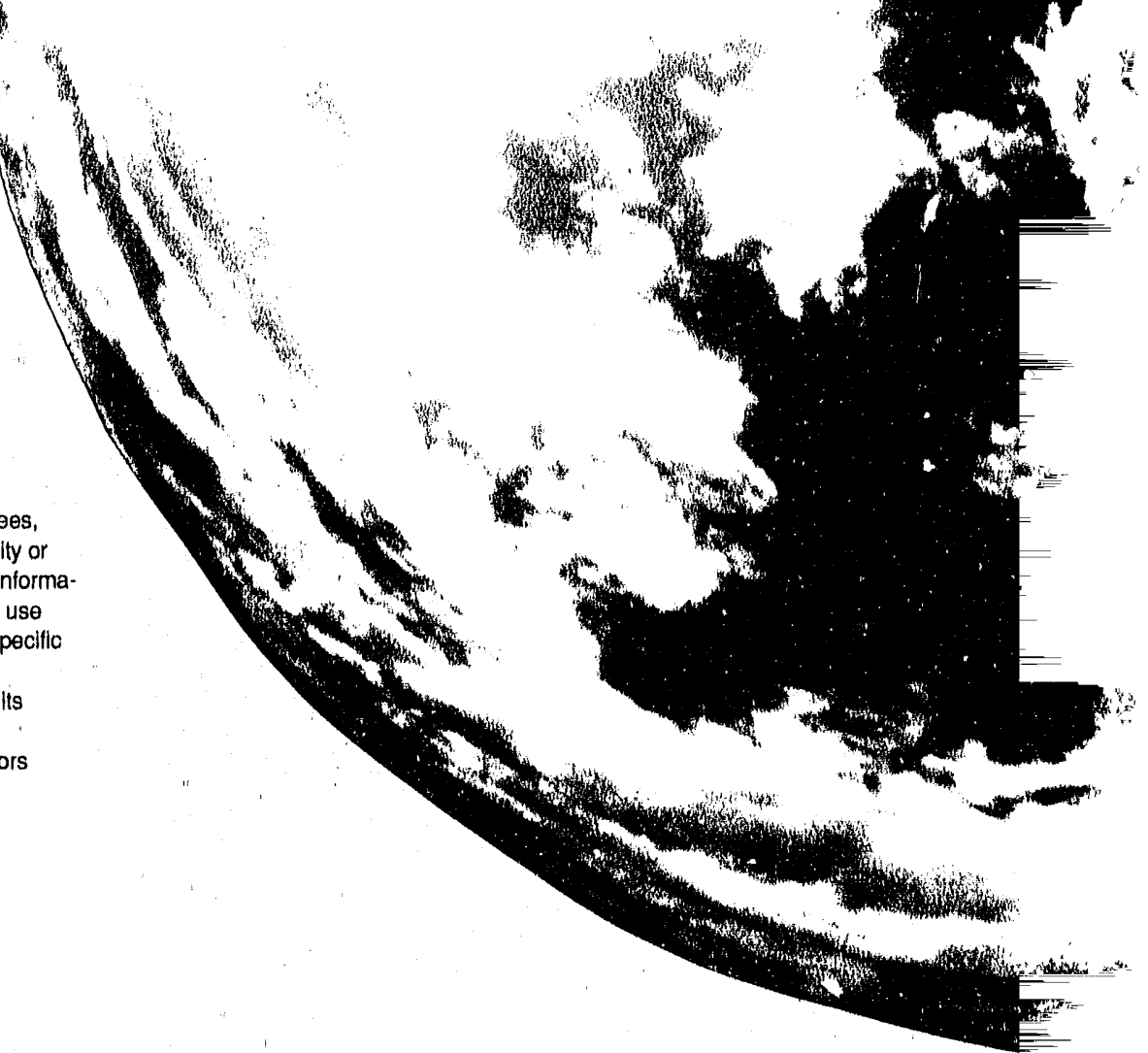




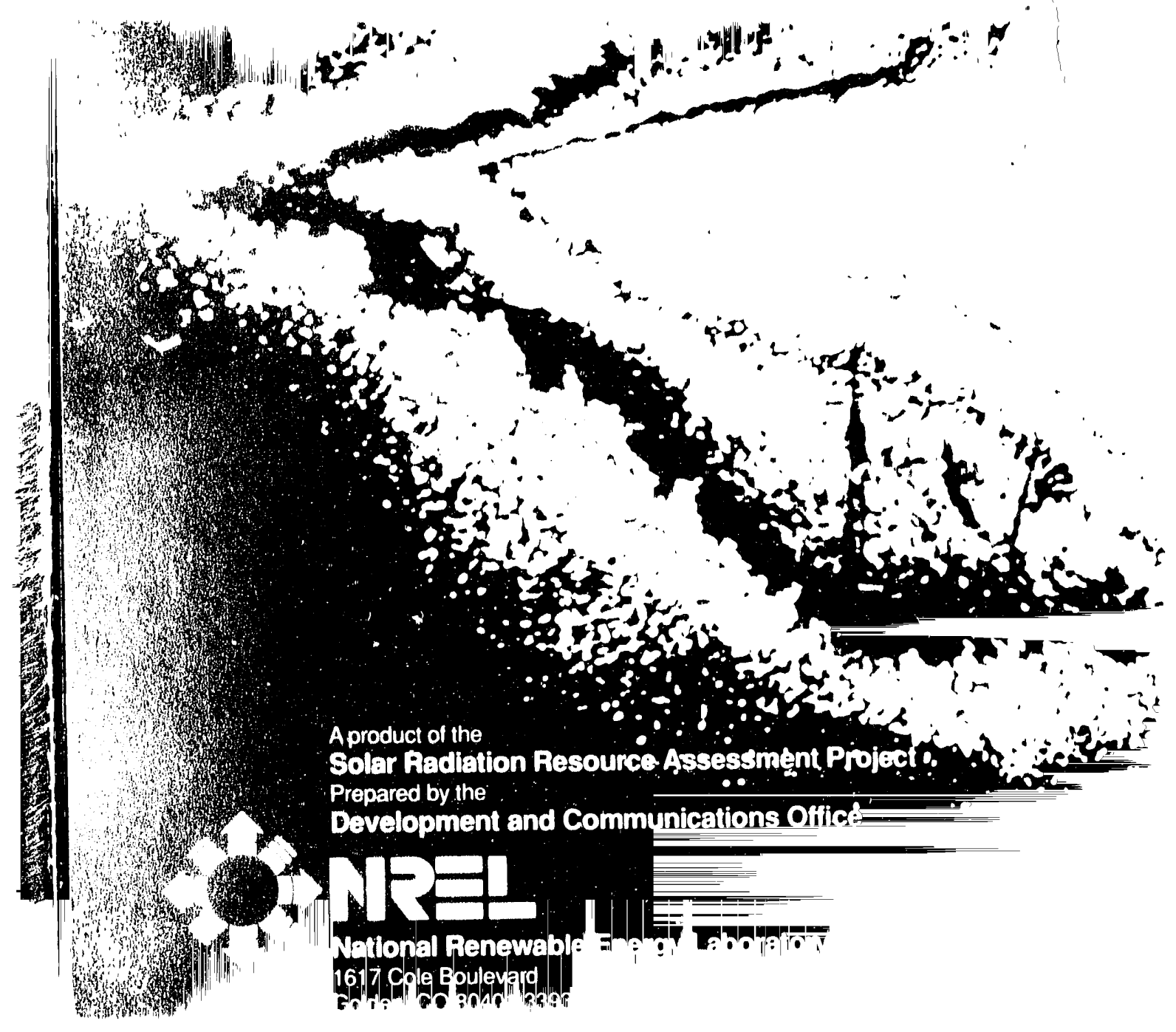




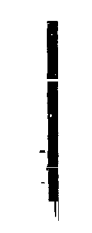

